\title{
شخصيات الوهراني في منامه الكبير بين النقد والسخرية*
}

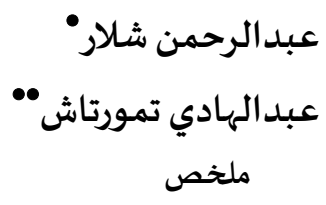

ركن الدين محمد بن محرز الوهراني (ت.تهOهـ) من أدباء القرن السادس، له (رسائل ومقامات

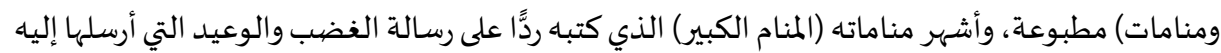

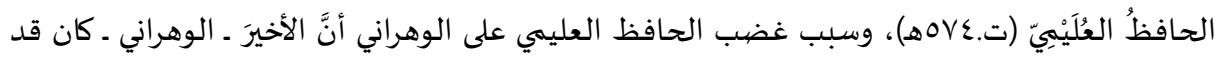

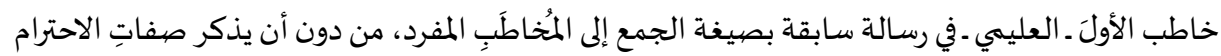
والتوقير.

وجاء المنام مملوءًا بالأحداث الخيالية المتسارعة التي تدور عجلتها يوم القيامة، إذ يبدأ المنام بخروج

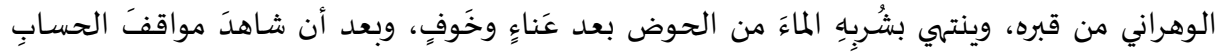
والتعذيبٍ وكشف حقائق الناسِ.

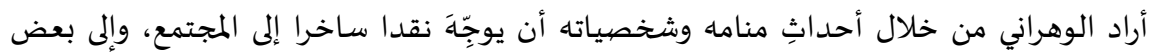

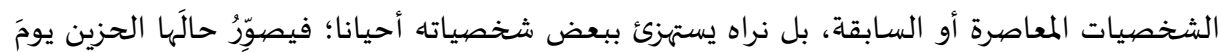

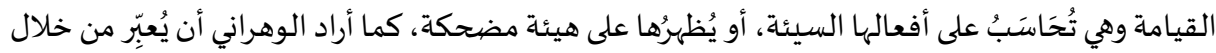
أحداث المنام عن بعض آرائه السياسية أو الدينية أو الاجتماعية.

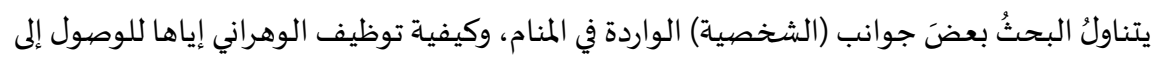

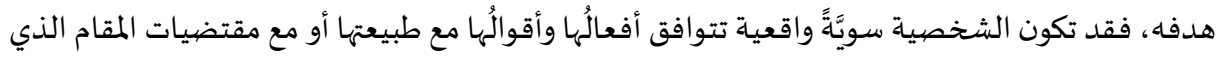

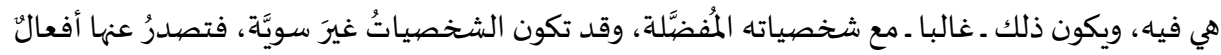

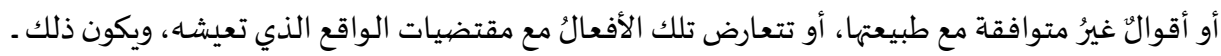

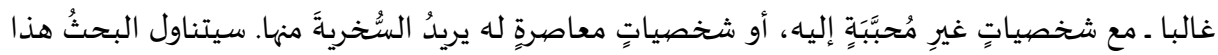

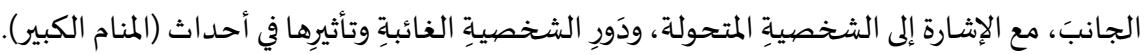

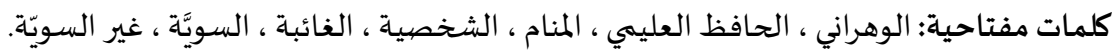

* Araştırma makalesi/Research article. Doi: 10.32330/nusha.909618

- Van Yüzüncü Yil Üniversitesi Sosyal Bilimler Enstitüsü Temel İslam Bilimleri Anabilim Dalı doktora öğrencisi. e-mail: mraho1980@gmail.com. Orcid No: 00000002-7335-6089

•• Doç. Dr. Van Yüzüncü Y1l Üniversitesi İlahiyat Fakültesi Öğretim Üyesi. e-mail: atimurtas71@hotmail.com. Orcid No: 0000-0002-6887-6223

Makale Gönderim Tarihi: 04.04.2021

Makale Kabul Tarihi $\quad$ :03.10.2021

NÜSHA, 2021; (53): 413-436 


\section{Eleştiri ve İroni Bakımından el-Vehrânî'nin el-Menâmu'l-kebîr Adlı Eserindeki Karekterler}

\section{Öz}

Altıncı Yüzyıl'ın önemli edebiyatçılarından olan Ruknuddîn Muhammed bin Muhriz el-Vehrânî’nin (ö. 575) Resâil, Makâmât ve Menâmât türünden eserleri vardır. Menâmât türünün en meşhuru el-Hâfız el-'Uleymî’nin kendisine gönderdiği öfke ve tehdit içerikli risalesine cevaben yazdığı el-Menâmu'lkebîr'idir. el-'Uleymî'nin el-Vehrânî'ye öfkelemesinin sebebi ise elVehrânî’nin daha önce el-‘Uleymî’ye yazdığı bir mektupta kendisine hitap ederken ikinci tekil hitap tarzıyla yetinip diğer saygı ve yücelik sıfatlarını kullanmamasıdır.

el-Menâmu'l-Kebîr, Kıyamet Gününde peşpeşe gelişen kurgusal olaylarla doludur. Rüya el-Vehrânî’nin Kıyamet Gününde dirilip kabirden çıkmasıyla başlıyor ve büyük korku ve sıkıntıları yaşayıp hesap ve azap sahnelerini görüp insanların hakikatlerini keşfettikten sonra Havz-1 Kevserden su içmesiyle son buluyor.

el-Vehrânî çalışmasında yer verdiği olaylar ve şahsiyetler aracıllğıyla toplumu, kendi çağındaki veya önceki dönemlerde yaşayan kimi şahsiyetleri eleştirmek ve hatta onlarla dalga geçmek istemiştir. el-Vehrânî ilgili kişileri Kıyamet Gününde dünyada işledikleri kötülüklerin hesabını verdikleri anki hallerini betimliyor veya onları maskara haline getirerek anlatıyor. Aynı zamanda el-Vehrânî rüyasında geçen olayları anlatırken bu vesileyle siyasi, dinî ve sosyal düşüncelerini de aktarmak istemiştir.

Araştırmamızın esas hedefi el-Menâmu'l-kebîr adlı eserde yer alan karakterlerin metinde hedeflenen sonuca varmak için nasıl kullanıldığını ortaya koymaktır. Nitekim eserde kullanılan karakterlerden kimisinin eylem ve sözleri kendi yapılarıyla uyumlu ve gördükleri göreve uygun düşen düzgün ve gerçekçi karekterler iken kimi karakterlerin söz ve eylemleri kendi tabiatlarıyla uyumlu olmamakla birlikte bulundukları konumlarına da yakışmayan düzgün olmayan karakterlerdir. Bu durum ise genelde sevilmeyen ya da kendileriyle dalga geçmek istenen yazarın çağdaşı olan karakterlerdir. Bunun yanı sıra değişken karakterler ile görünmeyen karakterlerin gördükleri görevin tespiti de yapılmıştır.

Anahtar kelimeler: el-Vehrânî, el-Hâfız el-'Uleymî, Rüya, Karakter Türleri.

\section{Al-Wahrani Characters in his Big Dream Between Criticism and Irony}

\section{Abstract}

Ruknuddîn Muhammed bin Mohriz al-Wahrânî (d. 575), who was one of the important literary figures of the Sixth Century, has works such as Rasâil, Maqâmât and Manâmât. The most famous of the Manâmât type is al-Manâm al-kabeer written by al-Hafez al 'Uleymî in response to the treatise of anger and threat he sent him. The reason why al-'Uleymî was 
angry with al-Wahrânî is that he used the second plural style of addressing and using other attributes of respect and exaltation when he addressed al-Wahranî in a letter he wrote to al 'Ulaymî earlier.

Al Manâm al Kabeer is full of fictional events that take place one after another on the Day of Judgment. The dream begins with the resurrection of alWahrânî on the Day of Judgment and ends with the drinking of water from Al Kawthar Basin, after experiencing great fear and troubles, and the group explores the truths of the people.

Al Wahrânî wanted to criticize and even make fun of some personalities in his own age or previous periods through the events and personalities he included in his work. Al-Wahrânî describes the situation of the people concerned while giving account of the evil they committed in the world on the Day of Judgment or by shows the characters as funny. At the same time, while telling about the events in his dream, al Wahranî wanted to express his political, religious and social thoughts.

The main goal of our research is to reveal how the characters in his work named al Manâm al Kabeer are used for the desired goal. As a matter of fact, the actions and words of some of the characters used in the work are smooth and realistic characters that are compatible with their structures and suitable for the task they see. This is generally the case for select characters. Although the words and actions of some characters are not compatible with their nature, they are irregular characters that do not suit their position. These are contemporary characters who are generally disliked or wanted to make fun of themselves. In addition, the task seen by variable characters and invisible characters was determined.

Keywords: al Wahrânî, al Hâfez al 'Ulaymî, Dream, Character Types.

\section{Structured Abstract}

The personality in the artwork - a story or a novel - is his beating soul, and his broad horizons, as it is the source and the engine of events, and without personality, events in the artwork would have been "childish and non-cultural things.

The personality in this research differs from it in others. Because the studied material is not a story, a novel, or a play, rather it is a dream that has restricted its events in al-Wahran in what is known as (the great dream), so the dream is a fictional event, and this imaginary dream dealt with an unseen event. On the Day of Resurrection, it became a fantasy in a fantasy, and in this respect it resembles the message of forgiveness for the nerd, as both of them chose the world of the afterlife to present their critical and literary issues.

Ruknuddîn Muhammed bin Mohriz al-Wahrâny (d. 575), who was one of the important literary figures of the Sixth Century, has works such as Rasâil, Maqâmât and Manâmât. The most famous of the Manâmât type is al-Manâm al-kabeer written by al-Hafez al 'Ulaymy in response to the treatise of anger 
and threat he sent him. The reason why al-'Uleymy was angry with alWahrâny is that he used the second plural style of addressing and using other attributes of respect and exaltation when he addressed al-Wahrany in a letter he wrote to al 'Ulaymy earlier.

Al Manâm al Kabeer is full of fictional events that take place one after another on the Day of Judgment. The dream begins with the resurrection of al-Wahrâny on the Day of Judgment and ends with the drinking of water from Al Kawthar Basin, after experiencing great fear and troubles, and the group explores the truths of the people.

Al Wahrâny wanted to criticize and even make fun of some personalities in his own age or previous periods through the events and personalities he included in his work. Al-Wahrâny describes the situation of the people concerned while giving account of the evil they committed in the world on the Day of Judgment or by shows the characters as funny. At the same time, while telling about the events in his dream, al Wahrany wanted to express his political, religious and social thoughts.

The main goal of our research is to reveal how the characters in his work named al Manâm al Kabeer are used for the desired goal. As a matter of fact, the actions and words of some of the characters used in the work are smooth and realistic characters that are compatible with their structures and suitable for the task they see. This is generally the case for select characters. Although the words and actions of some characters are not compatible with their nature, they are irregular characters that do not suit their position. These are contemporary characters who are generally disliked or wanted to make fun of themselves. In addition, the task seen by variable characters and invisible characters was determined. The study of these personalities starts from a literary angle that has nothing to do with the legal or historical aspect, so the Oranian talks about what he saw in his dream, and this is a fantasy, and every person sees in his dream what he sees, and his sleep does not affect his life.

The research aims to shed light on Al-Wahrany's personalities in his grand dream, how to employ them in social and religious criticism, the skill of blending two different worlds that do not really mix, and the extent of his success in expressing his principles and opinions, and in defaming his imaginary opponents with mockery and criticism.

Through this research, we find that Al-Wahrany intended criticism and ridicule, and he did not intend the scientific conversation about the Day of Resurrection. His dreams are primarily a response to the message of AlHafez Al-Ulaymy, and general social criticism was in the second degree. $\mathrm{He}$ dealt with the issue of hypocrisy, consuming money and bad professions, writers and doctors, and political differences had a large share in his sleep, especially Ali bin Abi Talib's dispute with Muawiya bin Abi 
Sufyan, through the followers of each team. Through the events of the alleged dream, Al-Wahrany employed his characters as follows:

Al-Wahrany was able to criticize society and individuals in a cynical way through a dream, and normal (real) personalities appeared clear, positive and influential, and non-normal (strange) characters appeared funny appearances that sometimes arouse pity and sarcasm at other times. Al-Wahrany employed the absent characters in a successful and often wonderful critical employment. He was also able in some of the characters to mix truth and fiction, so he worked a lot and failed a little. The bad ones with the forgiveness of God Almighty.

ا - تمهيد

الشيخ ركن الدين الوهراني من الفضلاء الظرفاء في القرن السادس الهجري، انتهج منهج الكتابة

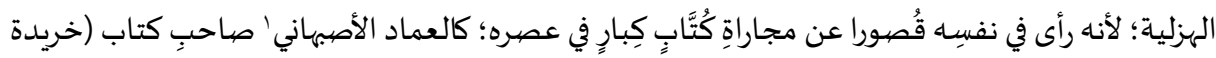

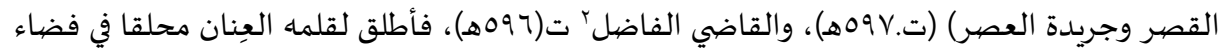

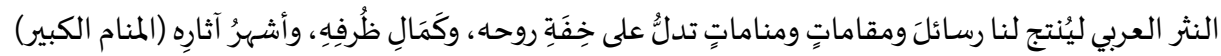

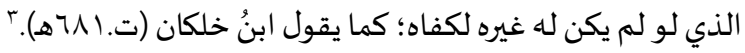

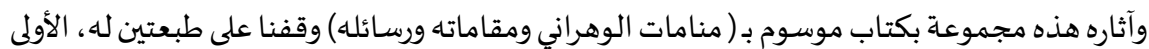

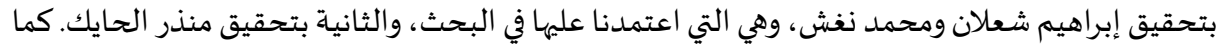

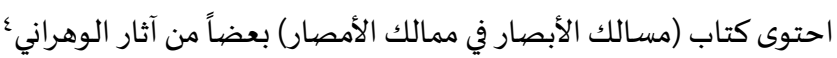

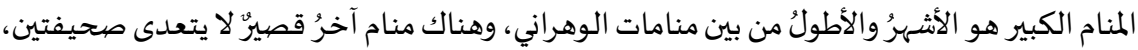

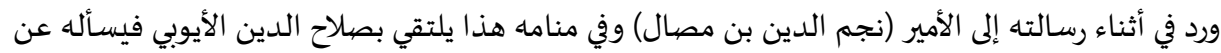

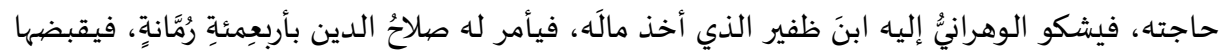

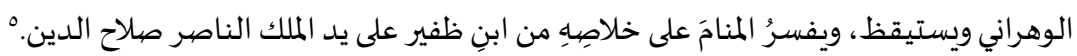

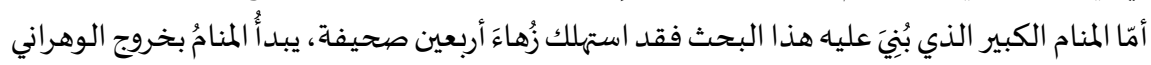

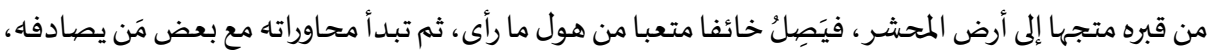

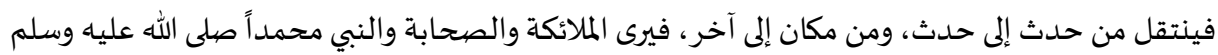

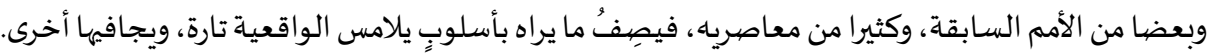

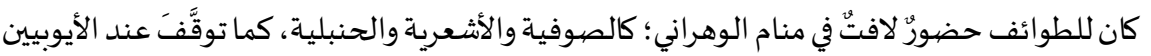

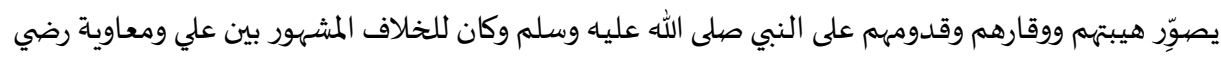

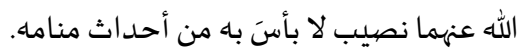

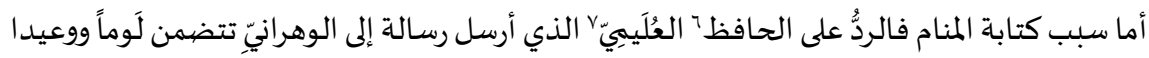

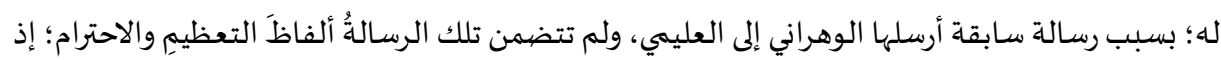


خاطب الوهرانيٌ العليميَّ فيها بصيغة المفرد لا الجمع، فما كان من الوهراني إلا أن كتب هذا المنام ليَرِدَّ باِ على الحافظ العليمي، وليوجاه نقدا وسخرية إلى كثيرٍ من معاصرياه وسـابقياه، بل نقدا اجتماعيا عامَّا.

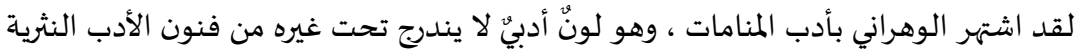

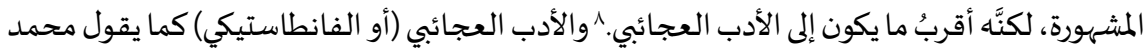

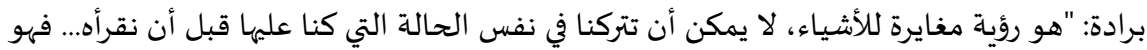

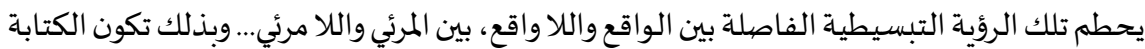

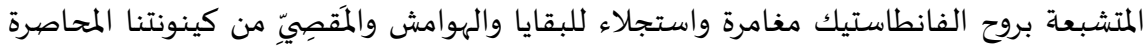
بضغط القوانين والمحرمات وشتى أنواع الرقابة". وهناك من يصنف المنامات ضمن أدب المقامات أو الرسائل؛ ذلك لأنَّ المنامات تحتوي على لمهن عناصر مشتركة بينهما · وهناك من جعلها أنموذجا للمسرح العربي التراثي الساخر " ، وعليه فلن يكون

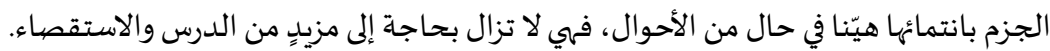

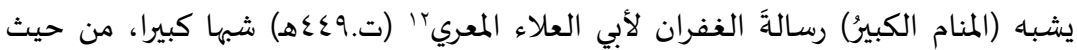

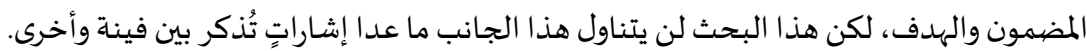
يهدف البحث إلى تسليط الضوء على شخصيات الوهراني في منامه الكبير، وكيفية توظيفها في

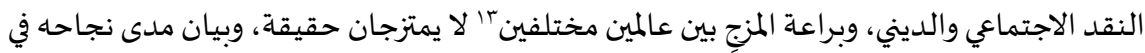

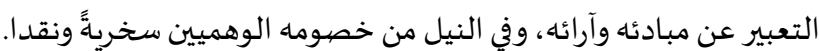

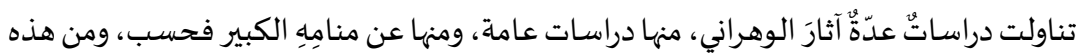
الدراسات: - الأديب المهاجر ابن محرز الوهراني، حياته ومسيرة هجرته، للكاتبة: مريم مناع، مقالة منشورة،

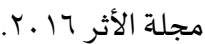
- التقديم والتأخير بين القاعدة النحوية والقيمة البلاغية في منامات الوهراني، للكاتبة أميرة قطيط، رسالة ماجستير، جامعة العربي بن مهيدي، الجزائر، 17 . ب.

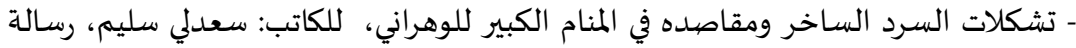
ماجستير، جامعة مولود معمري تيزي، الجزائر. - المنامات لون نثري في الأدب العربي (دراسـة في المنام الكبير للوهراني) للكاتب: علاء الدئي الدين محمد

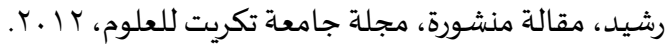
-الوهراني اللائذ بالعالم الآخر، للكاتبة: عطية فاطمة الزهراء، مقاهُهالة مقالة منشورة، جامعة محمد خيضر، بسكرة، عا . Y. - رسائل ابن محرز الوهراني، الموضوعات والأسـاليب، للكاتبة: مريم مناع، أطروحة دكتوراه،

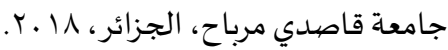

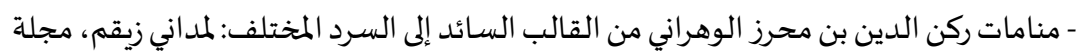

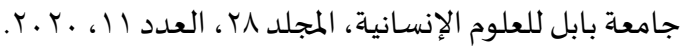


- موضوعات السرد في منامات الوهراني- قراءة وصفية: لمحمد صالح، مجلة إشكالات في اللغة والأدب،

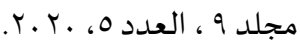

- السّخرية بين التجلي والقصديّة في المنام الكبيرللوهراني: لعمر حميداتو و العيد حنكة ، مجلة علوم

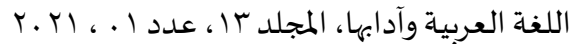

ويختلف هذا البحث باقتصاره على دراسة شخصيات المنام الكبير، ودراسة جوانبها من حيثُ مَنـِقِيَّةُ الأفعال التي تقوم بها أو غرابهها، علاوة على الشخصياتِ المتحوِّلة، والشخصياتِ الغائبةِ ودورِها في أحداث منِ

سيكون هذا البحث مبنيا على تمهيد يعقبه مبحثان تليهما خاتمة فنتيجة، يُخصيَّص التمهيد للحديث

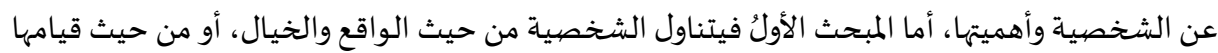

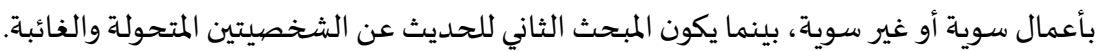
ودراسـة هذه الشخصياتِ تنطلق من زاوية أدبية ليس لها علاقة بالجانب الشرعي أو التاريخي، فالوهرانيّ

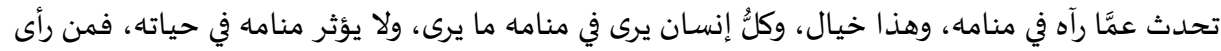
نفسَاه في نوماه يؤدي فريضة الحج لا يسقط عنه الحج، ومن رأى نفساه في نوماه يزني وهو محصن لا يجب عليهاه

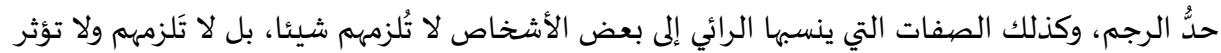

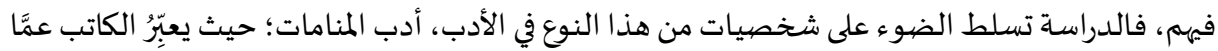

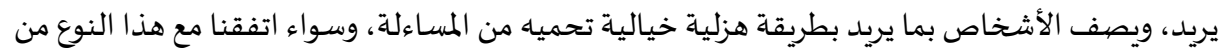

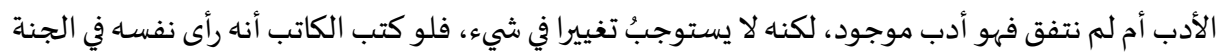

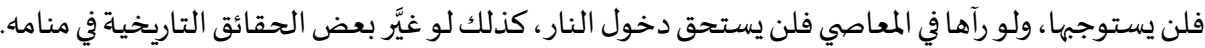

\section{r- الشخصية}

الشخصية في العملِ الفنيّ ـ أقصاًً كانت أم روايةً ـ هي روحُه النابضهُ، وآفاقُه الواسعة، فهي منبعُ

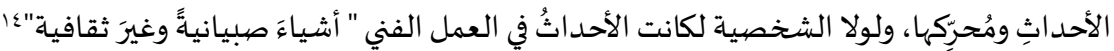

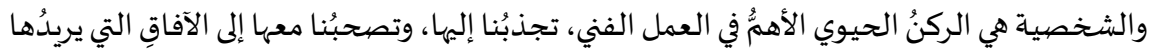

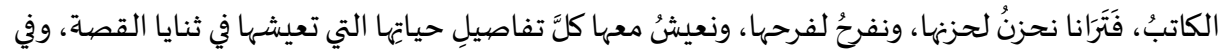

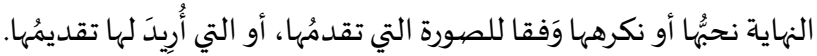

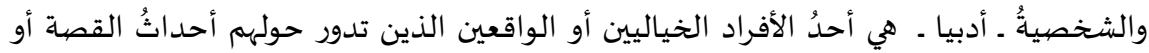

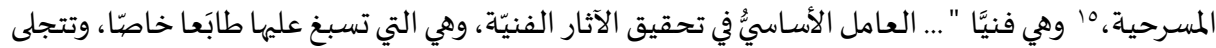
بوضوح في تصوّرِ موضيوعاتها، وفي تنفيذها، والأسلوبِ المُتَّبع فيها..." 17

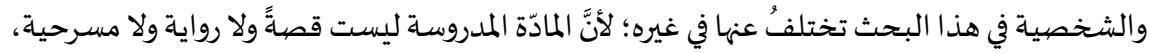

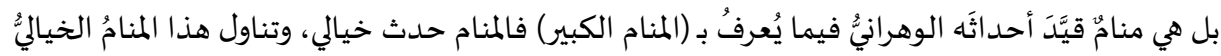

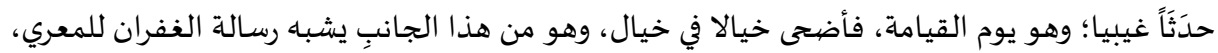

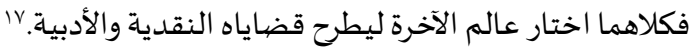




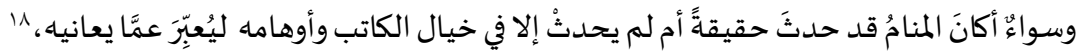

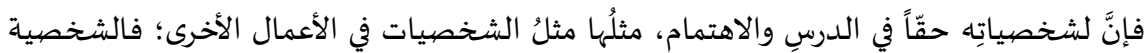

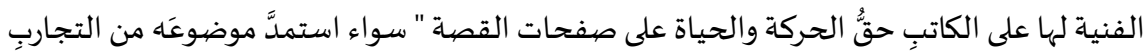

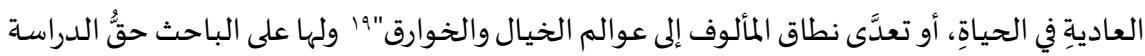
والاستنتاج. ولا بد قبل البدء بدراسة الشخصيات من الإشارة إلى أمر مهم يتعلق بشخصيات الوهراني،

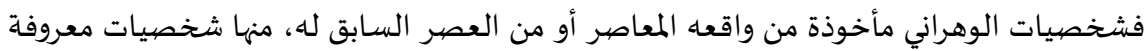

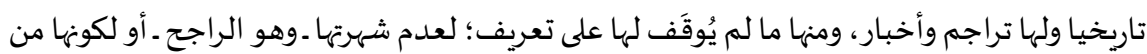

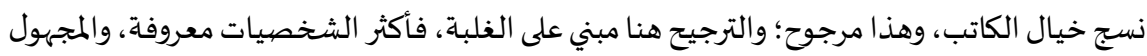

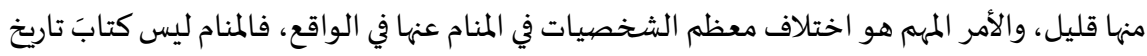

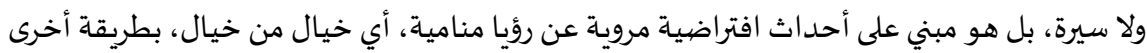

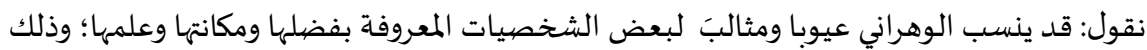

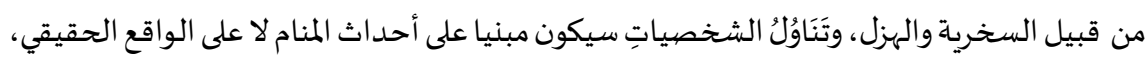

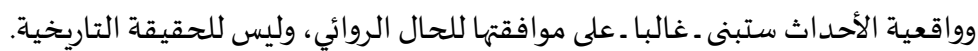
ترتبط الشخصية الفنية بالأحداث ارتباطا وثيقا، فالقارئ لا يعرف ملامح الشخصية ولئية وصفاتها

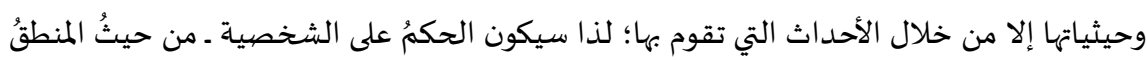

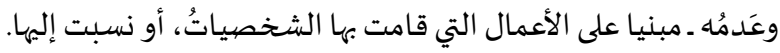

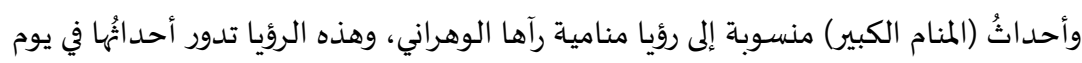

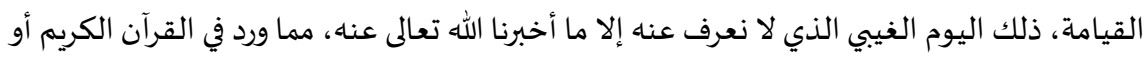

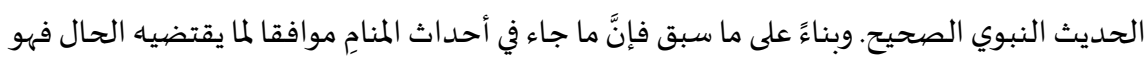

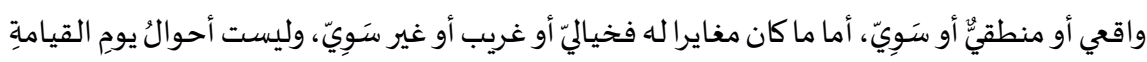

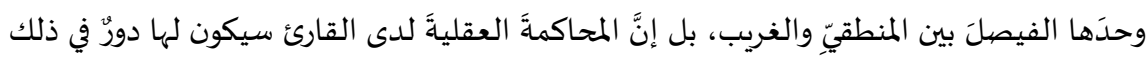

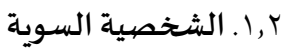

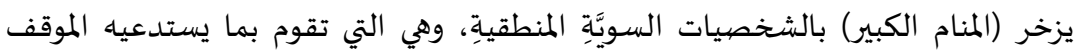

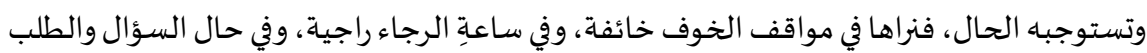
متذللة، وفي مَعرض الانتقام متجبرة وقاسية.

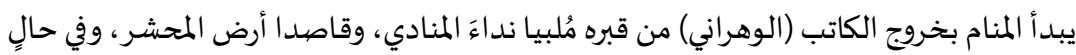

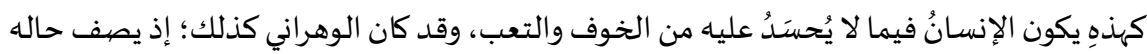

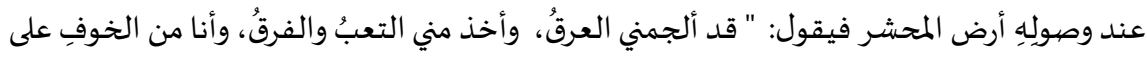

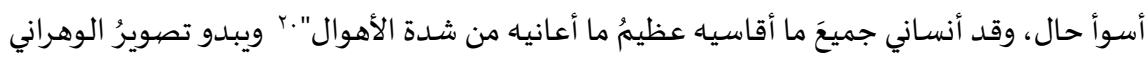

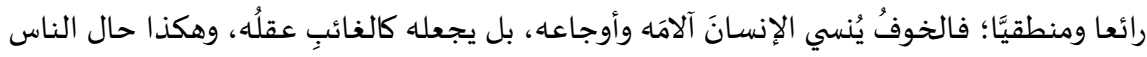




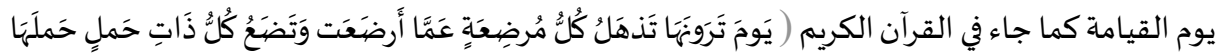

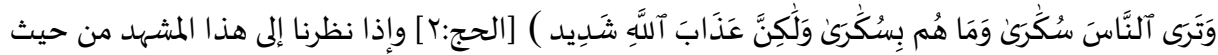

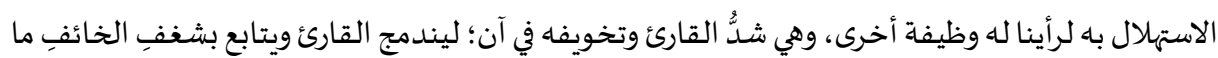
سيحدث بعد هذا الموقف العصيب.

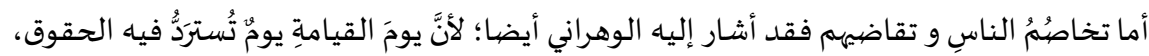

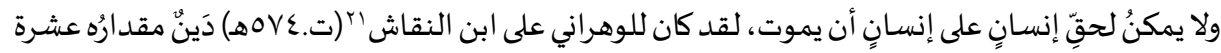

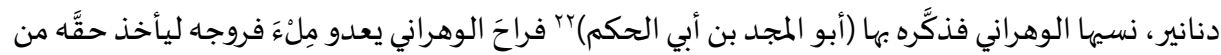

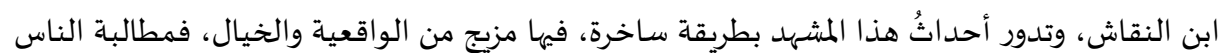

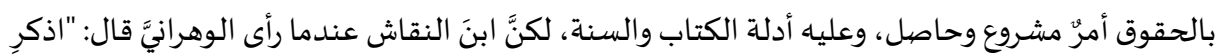

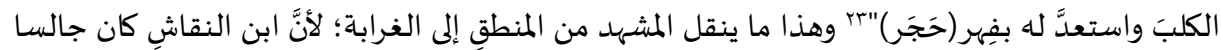

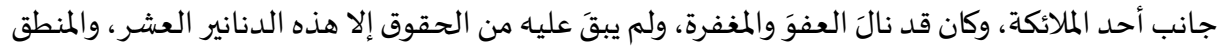
في مثل هذا الحال يستوجب ملاطفة الخصم واسترضاءه لا العكس.

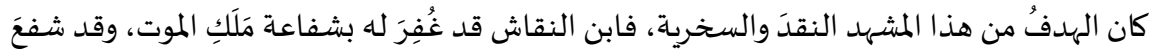

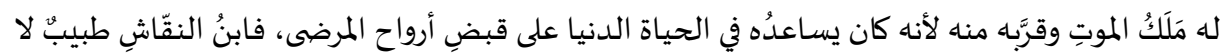

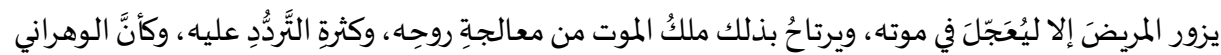

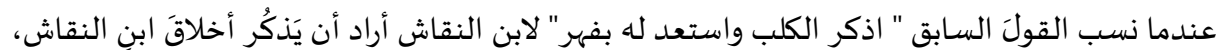

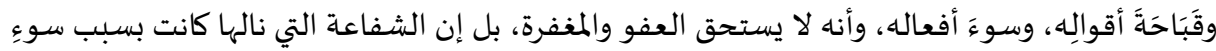

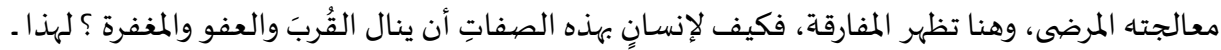

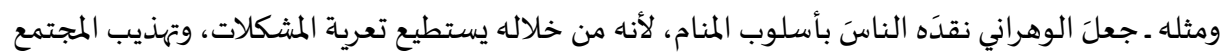

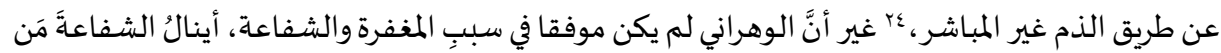

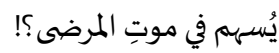
ثمَّ تتوالى الأحداث، ويتعرض الوهراني وصاحبـه الحافظ العليمي إلى كثير من المواقف الصعبة، يلجآن

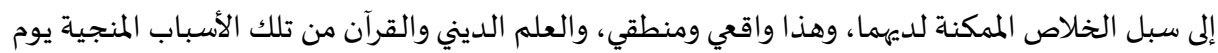

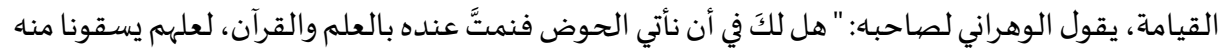

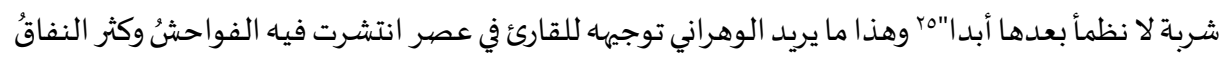

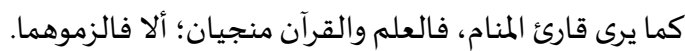

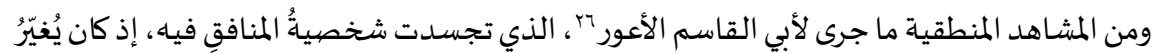

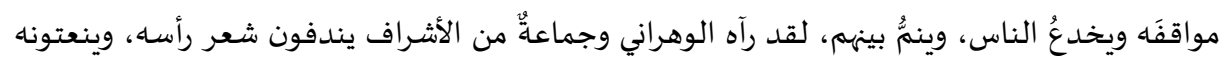

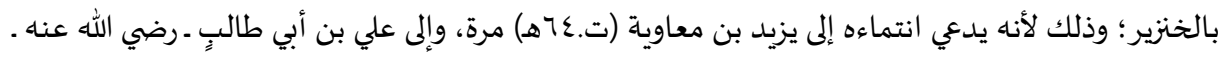

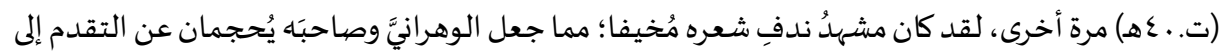


لقد تمَّ توظيف مشاهد أبي القاسم الأعور من نواحٍ عدة، فحجم الضربِ وشدته جعلا الوهراني

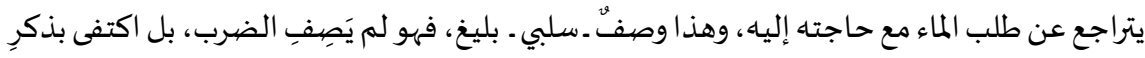

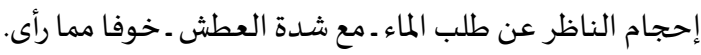

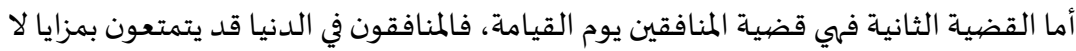
يَصِلُ إلهها غيرُهم؛ وذلك لأهم يملكون وجوها متعددة، يلبسـون في كلِّ مقام ما يناسبه منها، أما في الآخرة فمفضوحون، ولههم عذاب شديد، ولا يستطيعون النجاة. القضية الثالثة سياسية خالصية، وهي قضية الخلاف الشهير بين علي ومعاوية رضي الله عنهما،

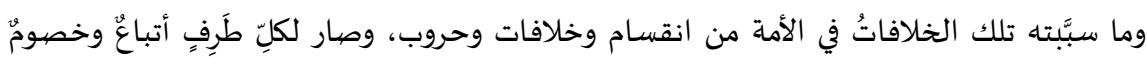

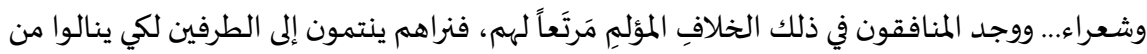
كل طرف غنائماه ولا يدفعون مغارماء.

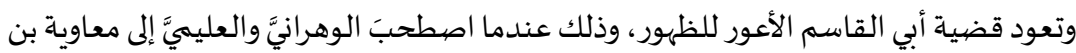

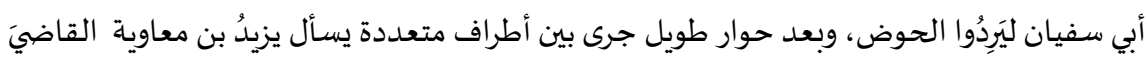

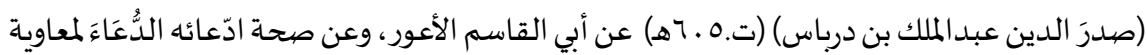

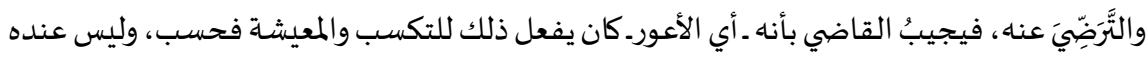
صددق في الانتماء، فلو جعل اليهودُ جُعلا على سَبِّ النبي صلى الله عليه وسلم لبادرَ الأعورُ إلى ذلك الك ولك مُسرعا، لا يصيده عن ذلك تقى ولا دين.

وهنا ظاهرة لابد من الوقوف عندها، وهي عِظَم خطورة النفاق والمنافقين، فلا دين لهم ولا مبدأ

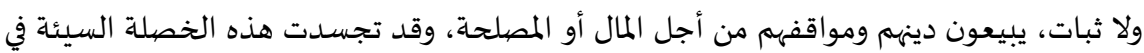

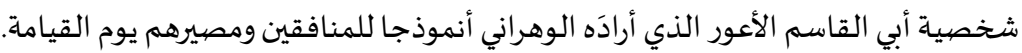

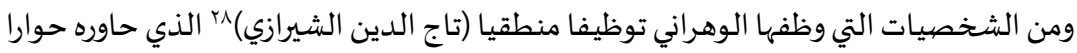

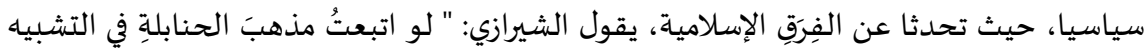

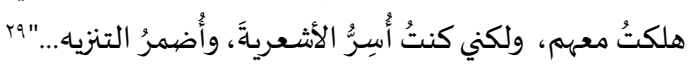

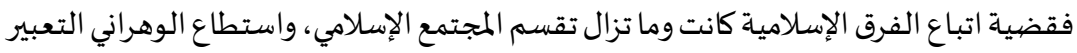

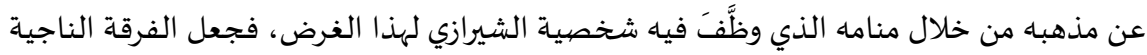

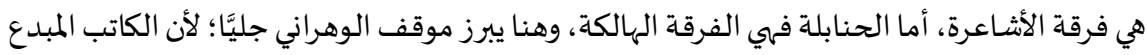

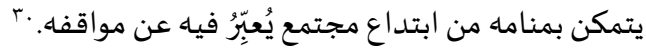

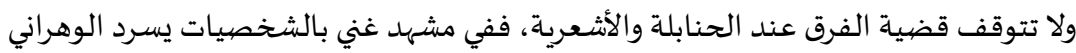

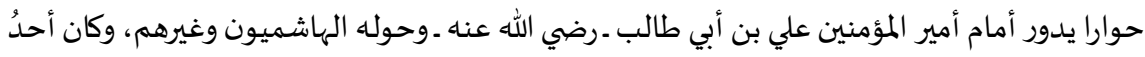

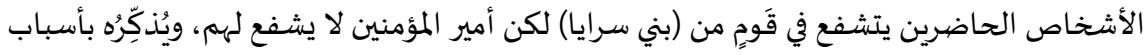

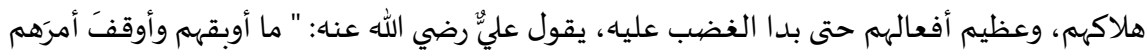

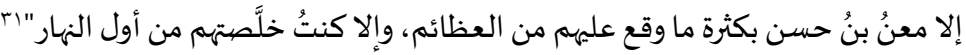


وهذا المشهد من المشـاهد الواقعية يوم القيامة، حيث يختصهم الناس، ويطلبون الشفاعة، ويسعون إلى إلى

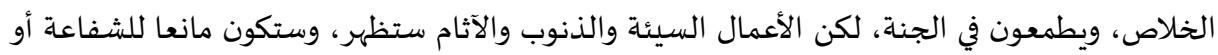

عائقا أمامها.

وعندما يتقدم الوهرانيُّ وصاحبُه من أمير المؤمنين يختبرهم ويطلب منهم البيّنة، فالمُدَّعون كُثُّر،

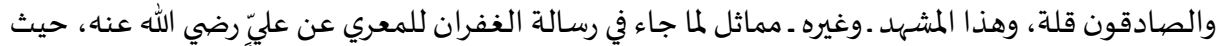

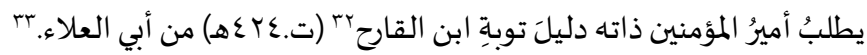

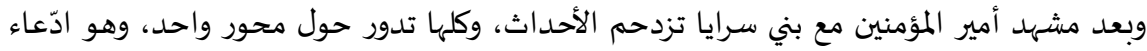

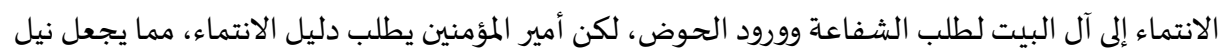
الشفاعة أمرا عسيرا على المدعين. ينتقل الكاتب بعد ذلك إلى مشهد عظيم، حيث النبي صلى الله عليه وسلم وحولم المهانه الجموع العظيمة

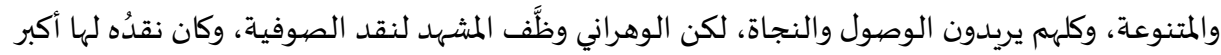

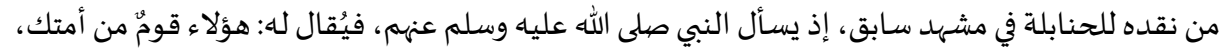

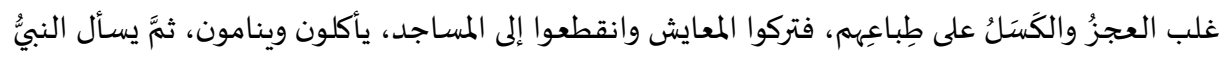

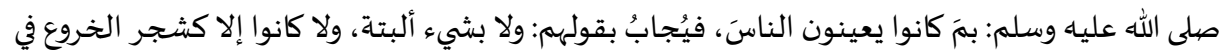

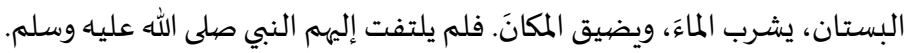
وهذا النقدُ سبقَه وصفُ هيئتهم عندما أقبلوا على النبي صلى الله عليه وسلم ، فهم كثيرون؛ لأنهم

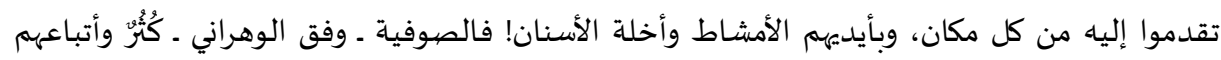
كثيرون، ويهتمون بالمظهر (الأمشاط والأخلة) فحسب، أمَّا نفعهم فمعدوم، وأما نومههم فكثير، وهم يستهلكون

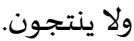

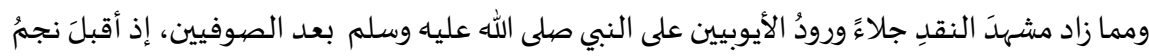

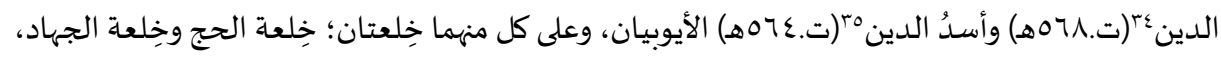

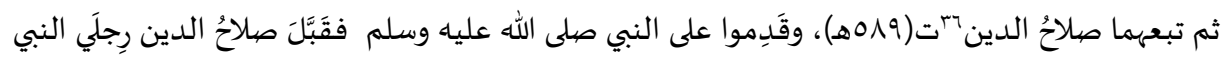

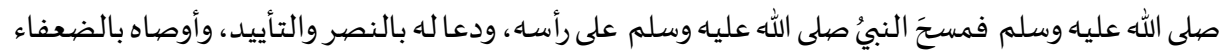
والمظلومين.

لم يكن ذكر الأيوبيين بعد الصوفيين اعتباطا، بل جاء من قِبَلِ الوهراني بقصدٍِ وعناية، وهو تفضيلُ

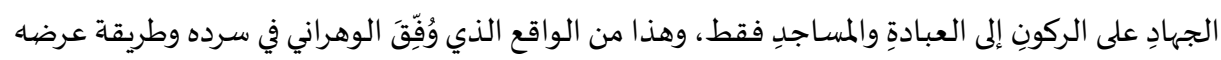
ومكانه في مجريات الأحداث.

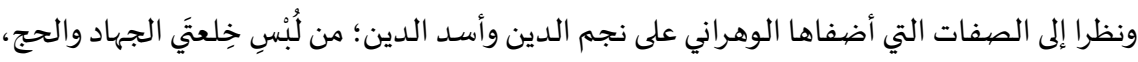

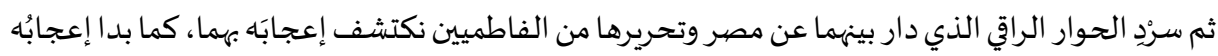

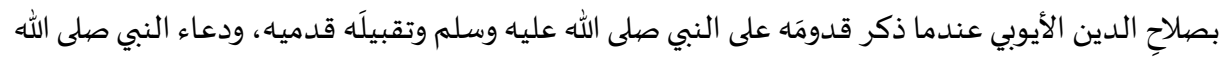

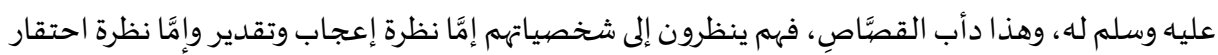

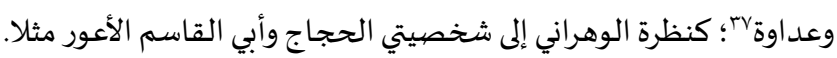


لقد عبََّّ الوهراني من خلال الأحداث السـابقِِ عن رأيه في الأشاعرة والصوفية وفي بني أيوب، أما

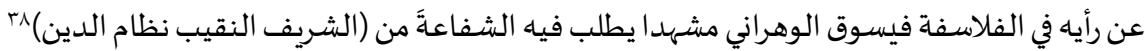

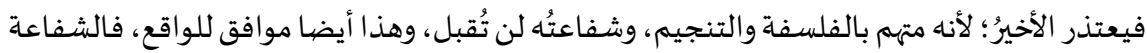

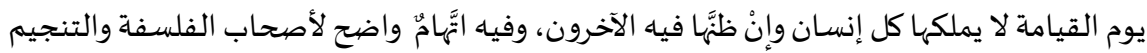

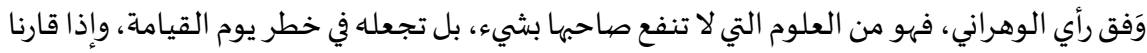

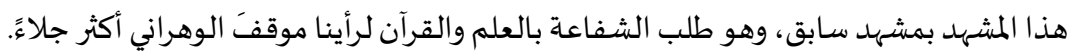

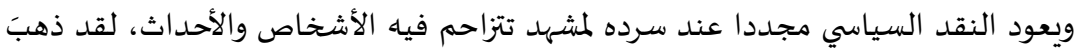

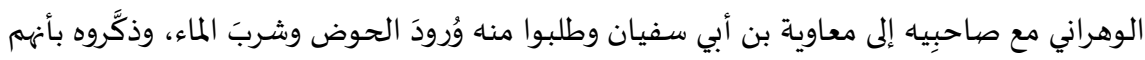

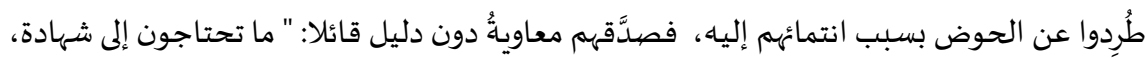

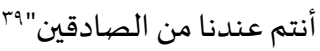

وبمقارنة هذا المشهد مع مشهد طلب الماء من علي كرم الله وجهها، نجد أن عليَّا رضي الله عنه طلب

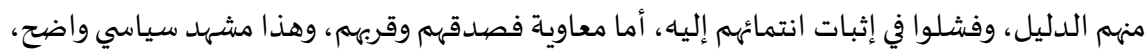
يعلن من خلاله الوهراني انتماءه وموقفاء. ويزداد الأمر وضوحا عندما يطلب يزيدُ بنُ معاوية منهما البيّنة، وتكون بيّنتهم القاضي (صدر

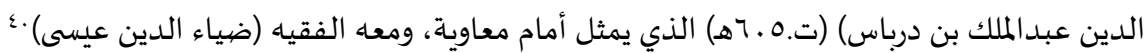

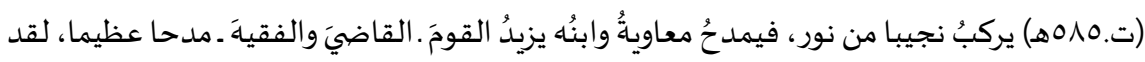

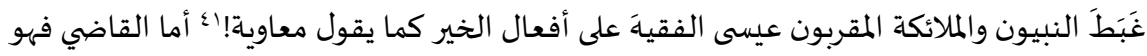
من عجائب الزمان وَفق قول يزيد. وتبدو المبالغة هنا تفوقُ طبيعة المقام، فكيف لنبي أن يغبط غيرَّه؟ والناس كلههم يتوجهون إلى

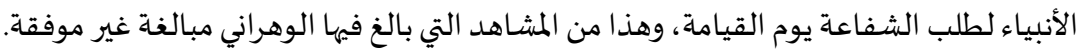

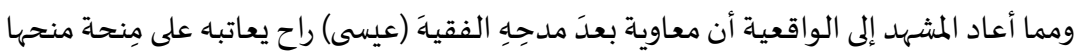

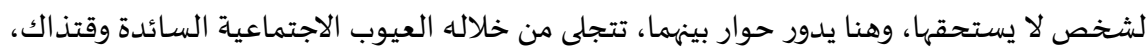

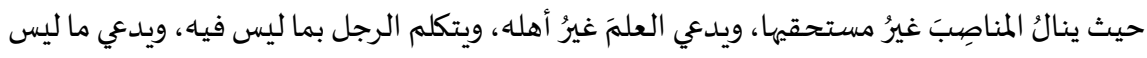

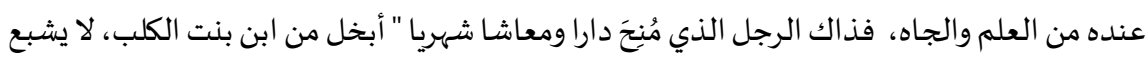

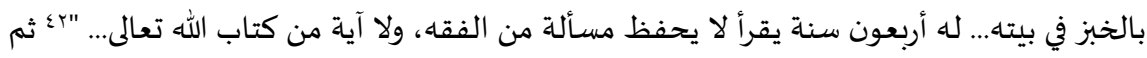

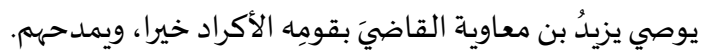

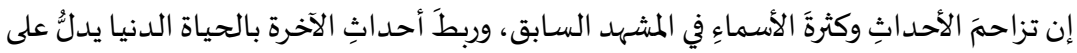

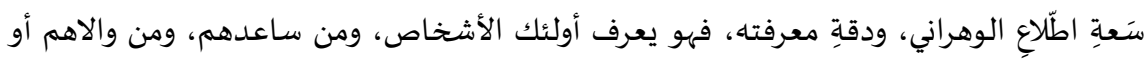

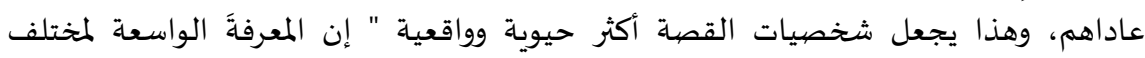

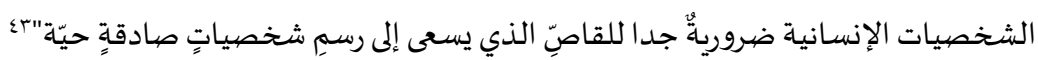

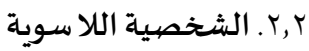


وفي الطرف المقابل للشخصية السوية نجد الشخصية غير السوية، تلك الشخصية التي قامت بما لا

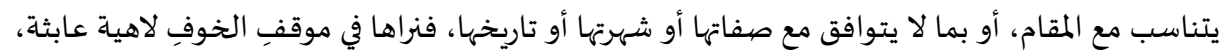

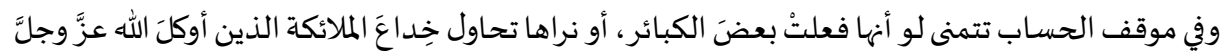

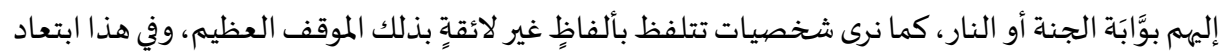

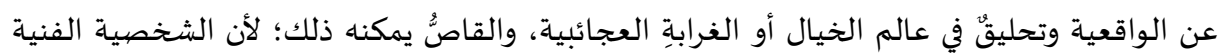
تختلف عنها في الواقع والحياة، فالفن والواقع متباينان. ؟

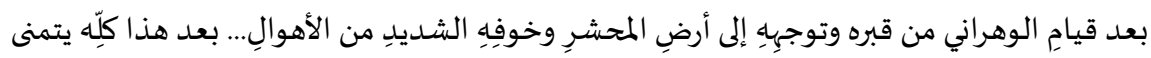

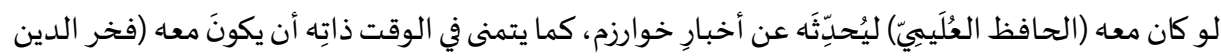

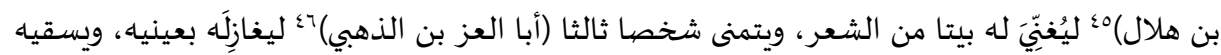

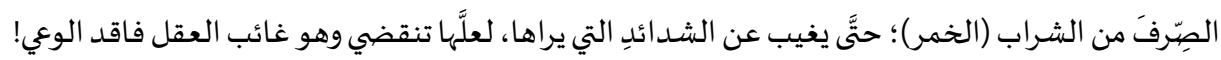

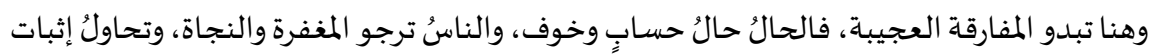
البراءة، وإبراز العمل الصالح، وكلٌّ مشغول بنفسه وبمصيره، فكيف للإنسان أن يتمنَّى سماع أخبار المدن

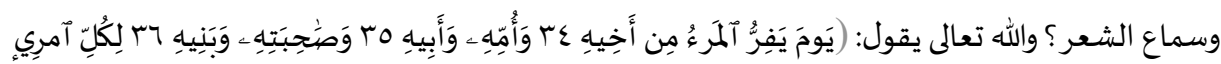

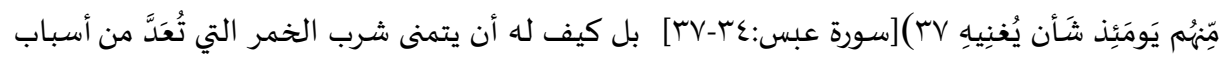

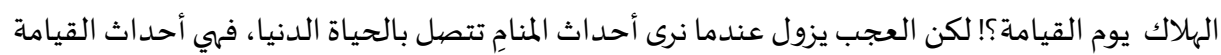

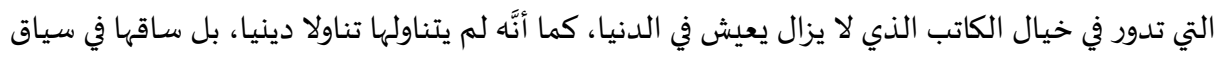
النقد والسخرية. ويخرج الوهراني عن مقتضى الحال والمقام مرة أخرى عندما يسمعُع بأنَّ الجواري اللواتي حملنَ منه في

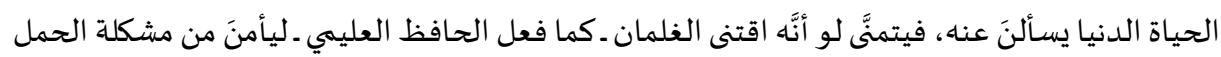

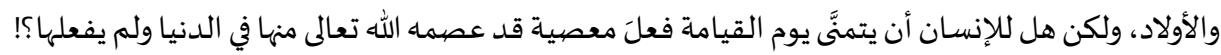

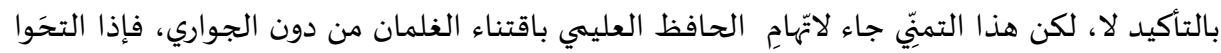

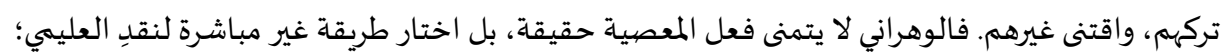

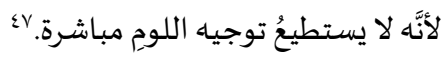

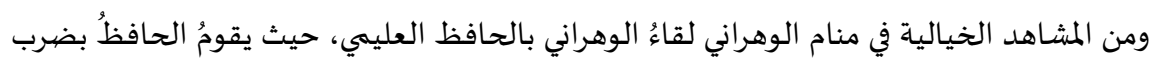

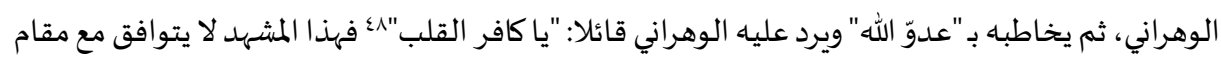

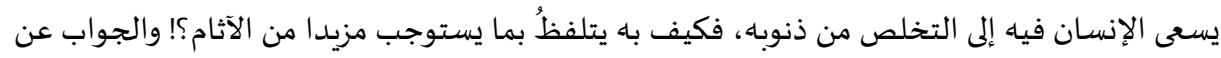

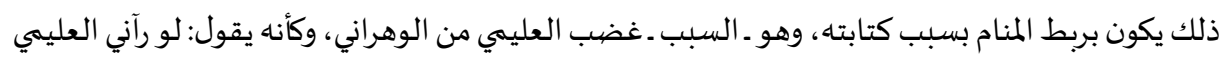

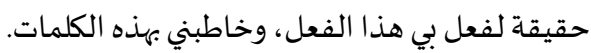

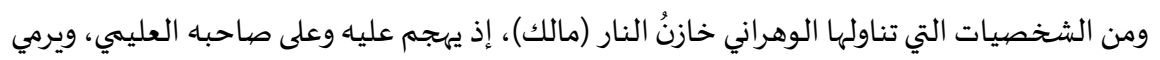

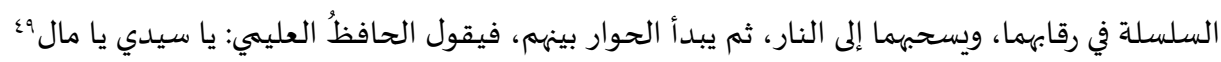

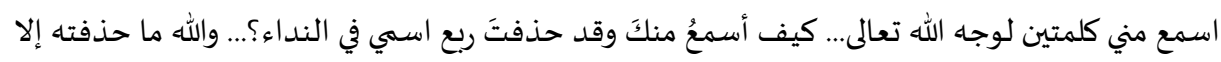


للترخيم في النداء الجائز عند جميع النحاة، وإنّي لفي شغل عن ذلك، وما حذفته إلا من شـدة الهلع

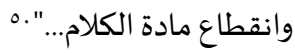

ويبدو الخيال في هذا المشهد من أوجه عدة، فمالك خازن النار ليس من وظيفته أن يطاردَ مَن

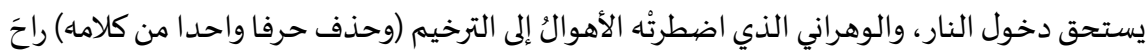

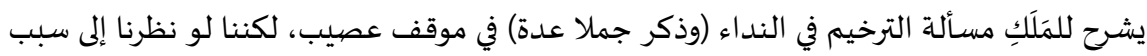

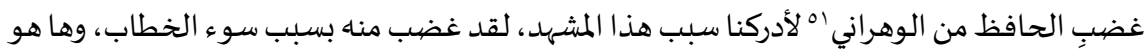

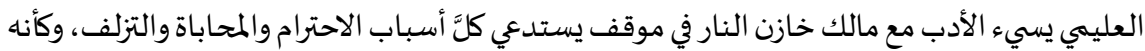

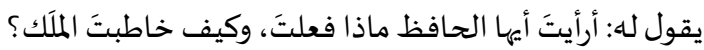

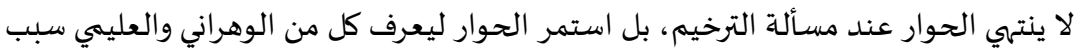

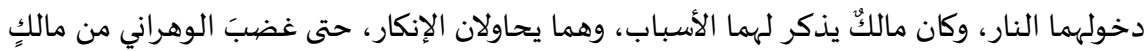

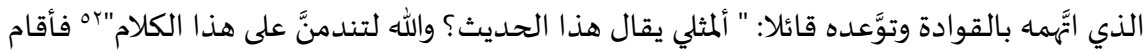

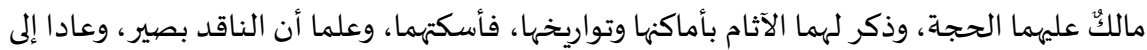

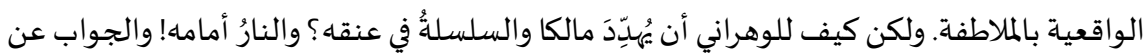

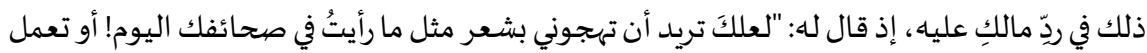

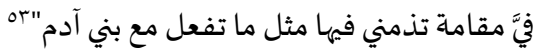

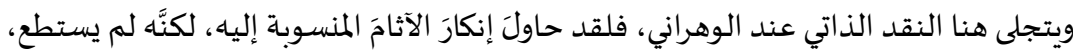

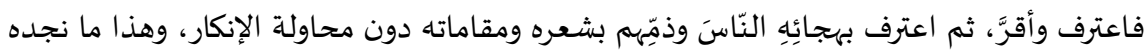

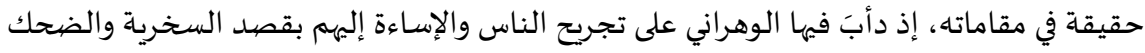

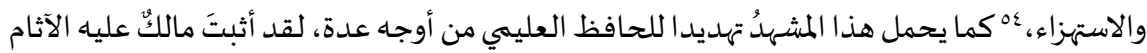

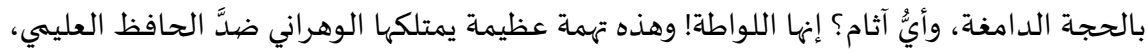

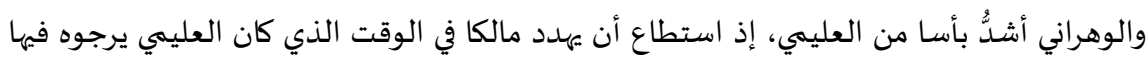

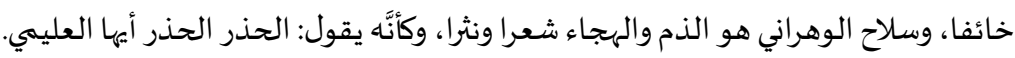

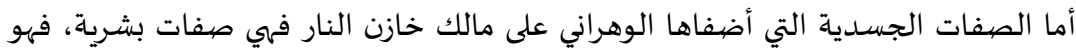

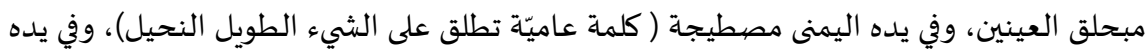

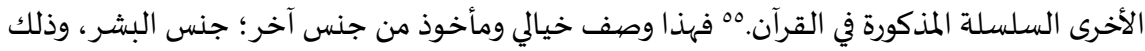

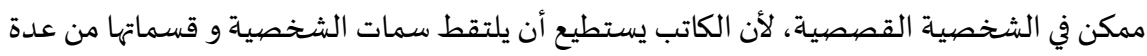

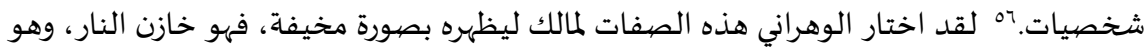

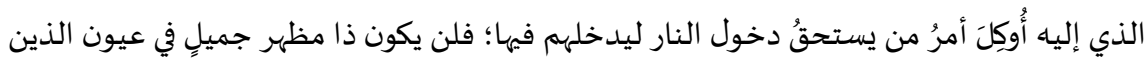
سيأخذ بهم إلى النار، ولعل هذا الوصف الخياليَّ مستوحيً من قوله تعالى: ( ...عليها ملائكة غلاظ

شداد...) [التحريم. 1) أما شخصية (أبي المجدد بن أبي الحكم) فقد أوردها الوهراني لينقد من خلالها كتاباتِ بعضِ كتَّابٍ

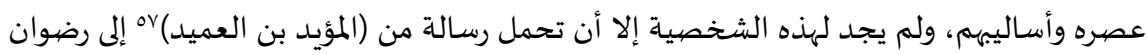


خازن الجنة يطلب فيها بعضا من ثمار الجنة، وهذا مشهد خيالي لا يتوافق مع ما ورد عن مشـاهد يوم القيامة،

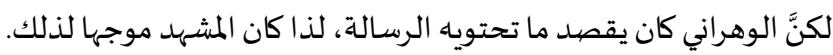

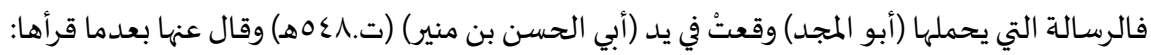

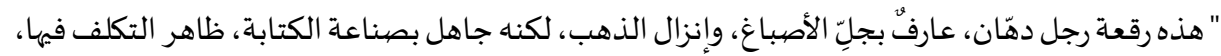

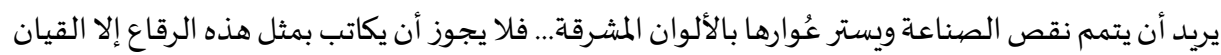

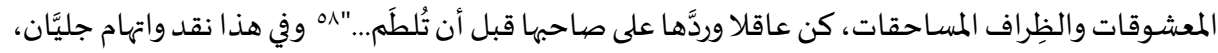
أما النقد فكتابة (ابن العميد) فيها نقص وعيوب، ولم يجد طريقة لستر عيوبه سوى الألوان والزخارف، وأما الاتهام فرقعته لا تصلح إلا للقيان والمعشوقات والمساحقات، ولعله يقصد أن (ابن العميد) اعتاد الكتابة إليهنَّ.

ومن المشاهد الخيالية التي أوردها الوهراني في منامه مشهد يضم أربع شخصيات، وهي عبدالرحمن بن

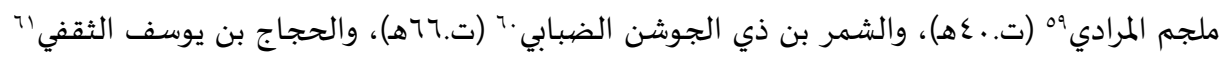

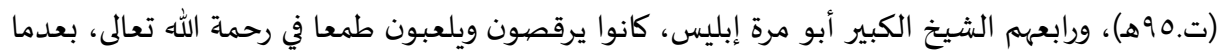

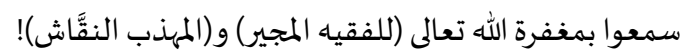

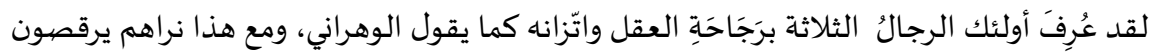

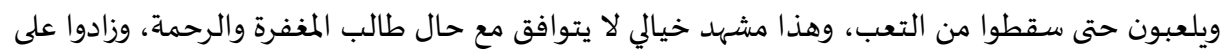

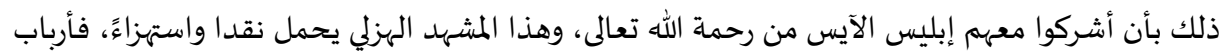
العقول والجبروت في الدنيا غدوا مهرجين وهزليين في الآخرة، وهم يطمعون بالرحمة لكنهم يشتركون مع إبليس

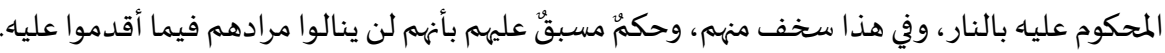

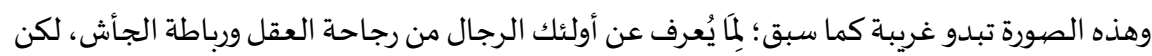

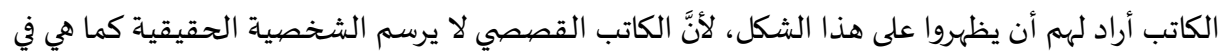

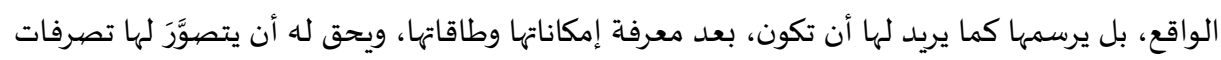

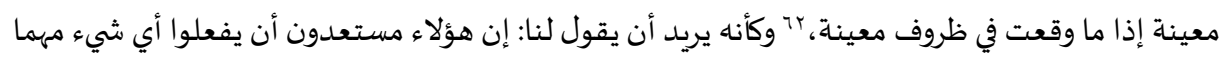
كان، طالما يوصلهم إلى بغيتهم، وكأنها يحدثنا عن البرغماتياة لديهيه.

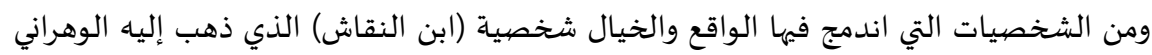

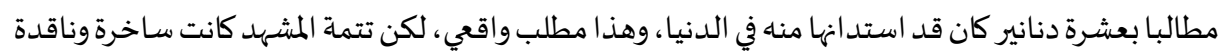

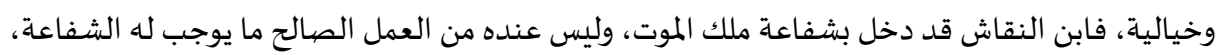
أما ملك الموت فشفع له لأنه كان يساعده على قبض أرواح المرضى الذين يعالجهم فيهلكهم ويعجل منئ منيتهم!

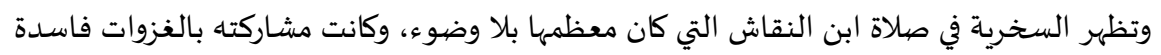

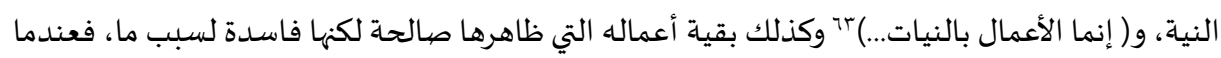

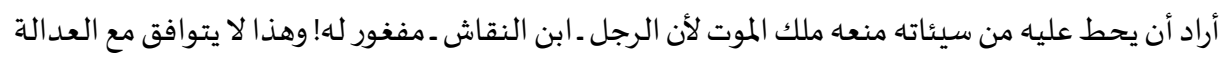
المطلقة المعروفة عن يوم القيامة، فلا تظلم نفس شيئا. 
ثم يطالب الوهراني بدلا من دنانيره بمكان في الجنة، فيجيباه ملك الموت بأنه لا يملك هذا الحق، ويُخيّره

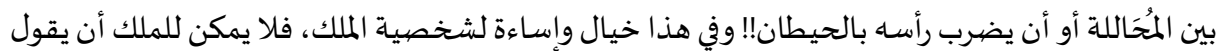
هذا الكلام.

وفي الهاية يتنازل الوهراني عن حقه لأنه لم يستطع استرداده، فيعده بأنه سوف يعيش في الدنيا بعد

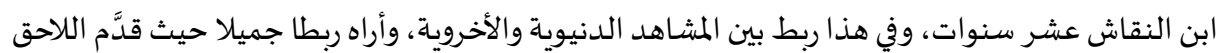
على السابق، وجعل الحقيقة في أثناء الخيال.

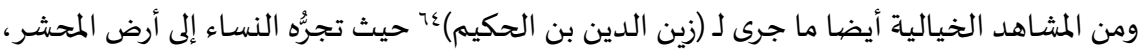
وبعض الناس يُحَرِّرُ عليه قائلا: ما يخلصك من هؤلاء في هذا اليوم لا شِعرك الركيك، ولا رسائلك الباردة... 10

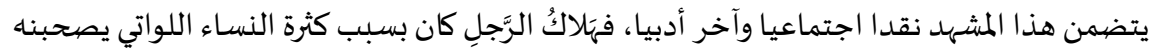

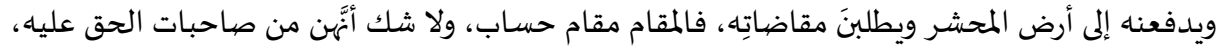

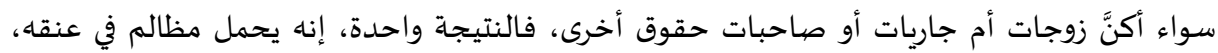

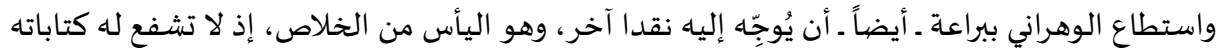
الأدبية بسبب سوئها؛ فالشعر ركيك، والرسائل باردة.

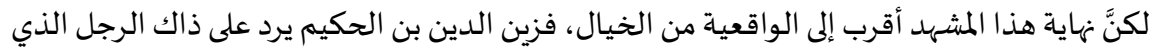

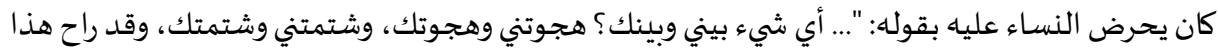

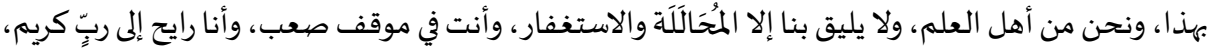

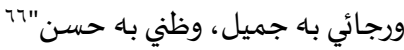

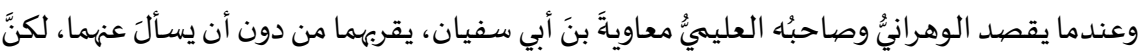

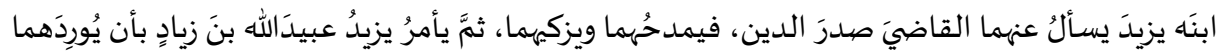

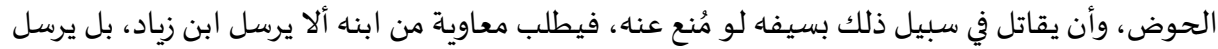
بدلا منه (ذا الكلاع) وذلك بسبب الدماء التي بينهم لآ حتى خشي الوهراني من صهفين أخرى في الآخرة.

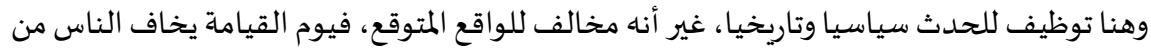

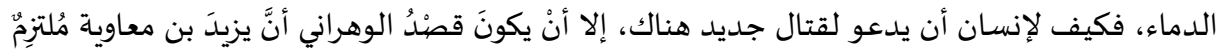
بإحقاق الحق بسيفه في الدنيا والآخرة. r. الشخصية بين التحوّل والغياب التحول في الشخصية يشبه الغياب؛ لأن التحول يعني غيابَ صفاتها السابقة وخصيائصها،

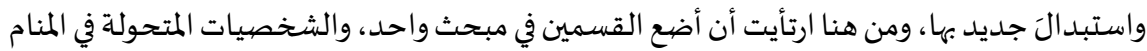
قليلة، وهي الوهراني وصاحبه العليهي، إلا إذا ربطنا بين الحياة الدنيا والآخرة الافتراضية في خيال

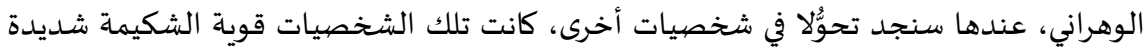

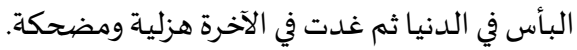


تتعرض الشخصية في أثناء الأحداثِ إلى التطور والنمو، وبعض الشخصيات يطرأ عليها تغيير كامل،

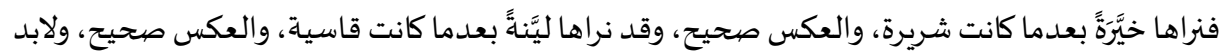

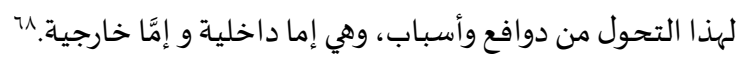

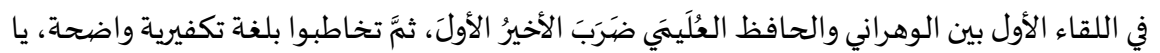

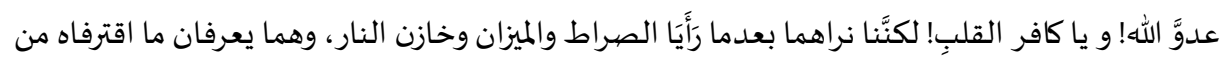

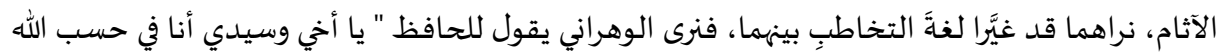

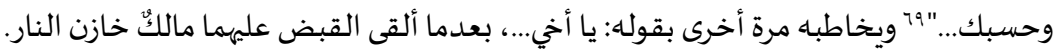

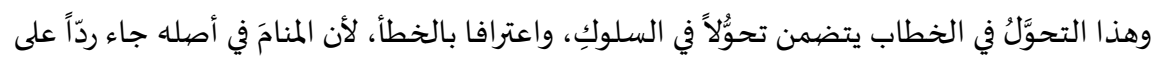

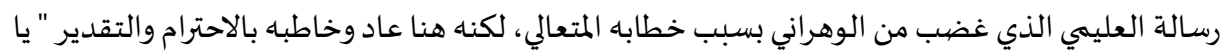

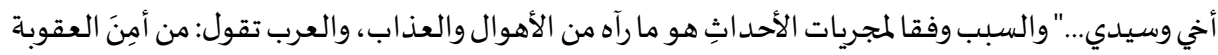

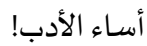
كذلك فعل العليمي، فبعدما كان يهدد الوهراني بالعقوبة والشكوى، صار يُحذّرُه من مواطن الهلاك،

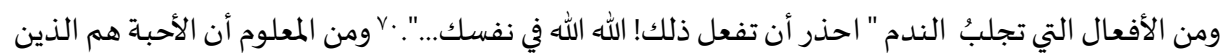
يتناصحون وليس الأعداء! وللعليمي موقف آخر مماثل؛ وذلك بعد انتهاءٍ الوهراني من محاورة ملك الموت، إذ يقول العليمي

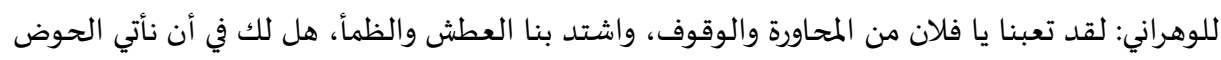
فنمتَّ عنده بالعلم والقرآن.

ويبدو أنَّ سببَ التحوُّلِ هنا خارجي، وهو رؤية العذاب والأهوال، أما هدفه فهو النجاة من الأهوال.

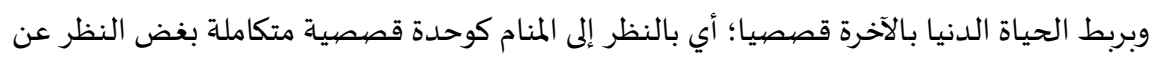

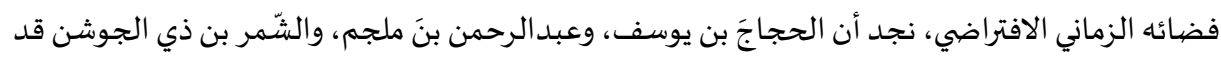

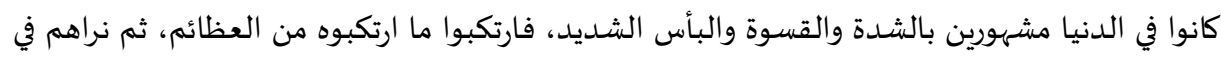

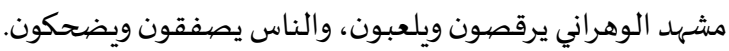

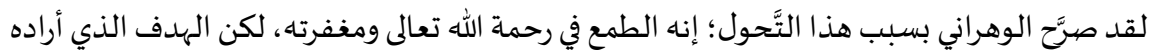

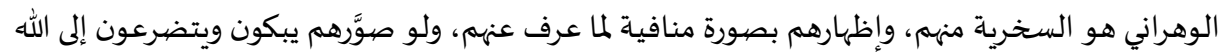

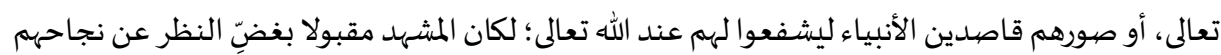

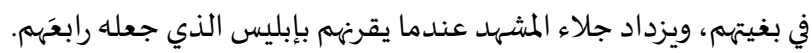

\section{r.r. الشخصية الغائبة}

ومن الشخصيات الجديرة بالدرس تلك الشخصيات التي لم نشاهدها في أحداث المنام، بل كانت حبيسة

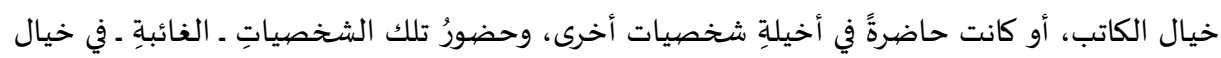

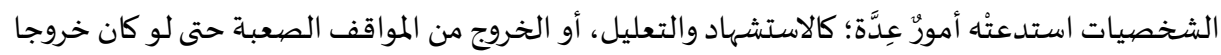

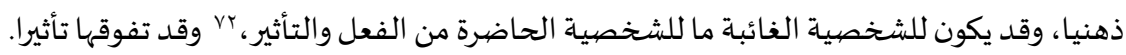


الحافظ العليمي يحضر في خيال الكاتب قبل أن يحضرَ حقيقةً في أحداث المنام، فعندما يواجه

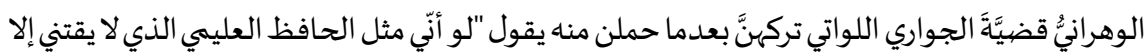

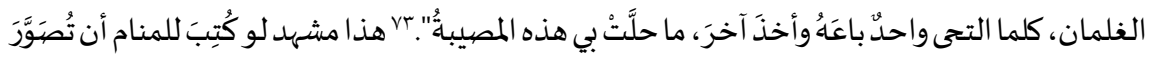

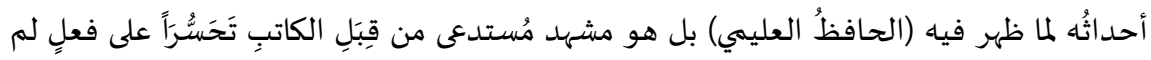

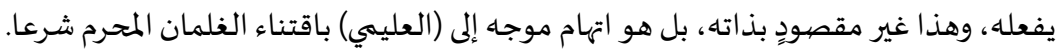

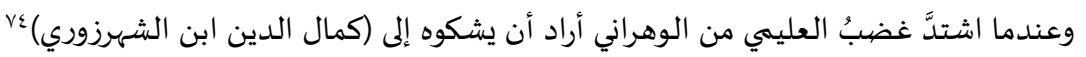

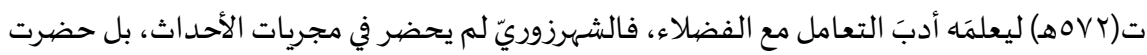

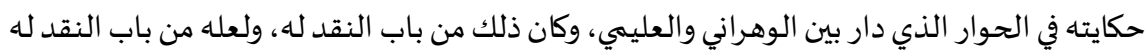

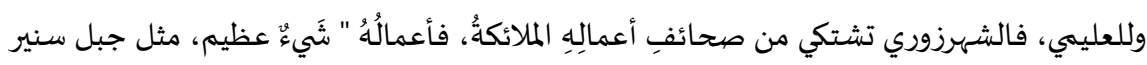

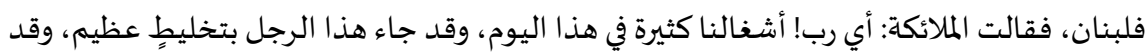

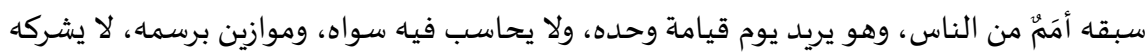
فيها غيره...

لكنَّ الشهرزوري ـ مع كثرة صحائفه ـ يدخل في شفاعة جبريل عليه السلام ويعفو اللهُ تعالى عنها،

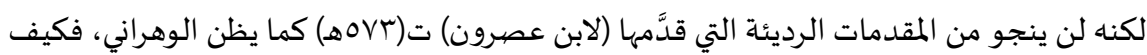

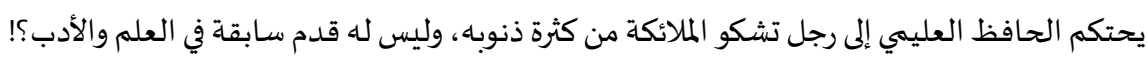

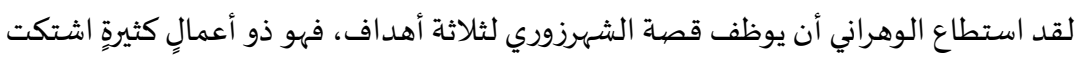

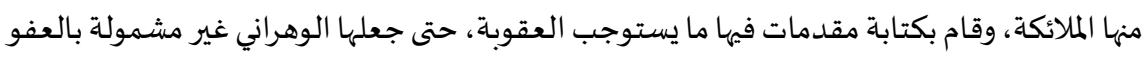

الإلهي وشفاعة جبريل عليه السلام، أما الهدف الثالث فاعتماد الحافظ العليمي عليه لينصفيه.

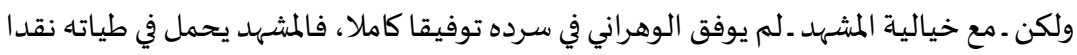
للعليهي الذي استنصر به، وهذا نقد محق، ولكن كيف ينسب الوهراني لله تعالى مَففرةً وعفوا عن رجلٍ كثيرِ الذنوب، دون ذكر أسباب ذلك.

ومن الشخصيات الغائبة التي تمَّ توظيفها للنقد الأدبي شخصية (المؤيد بن العميد) من خلال الرقعة (الرسالة) التي بعث بها إلى (رضوان) خازن الجنة يطلب بعضيا من فاكهتها، فابن العميد لم يحضير

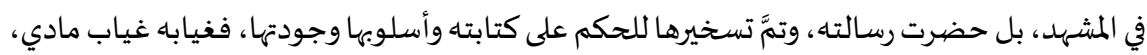
لكناه حاضر معنويا. ولم يكتفِ الوهراني بنقد رسالة (ابن العميد) من قِبل (أبي المجد) بل راح يحكي قصهة أخرى على ألى

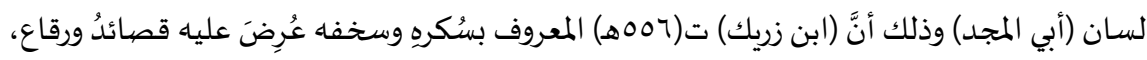
ومن بينها رقعة لابن العميد " فيها سطر مكتوب بالأخضر اليانع، وسطر بالأصفر الفاقع، وسطر

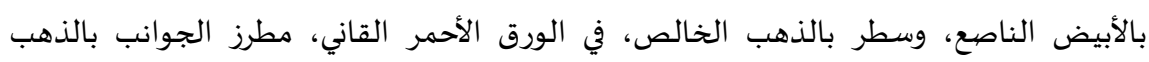

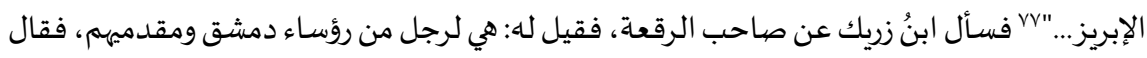

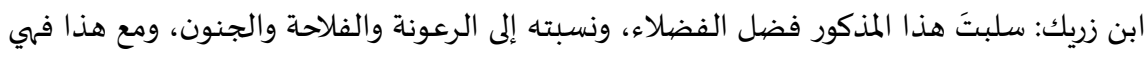

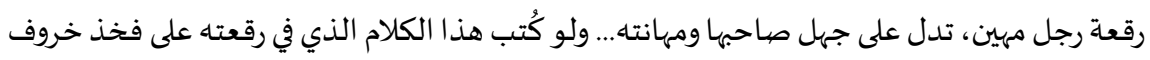


سمين وألقي على الطريق لأنفت من أكله الكلاب! ويختم ابن زريك نقده بقوله: هؤلاء فضلاء الشام، ورؤساء

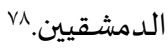

والنقد السـابق ـ لا شكَّ ـ شـديد، وشـدته مضياعفة، إذ لم يكتفِ الوهراني بنقد (أبي المجد) لابن العميد،

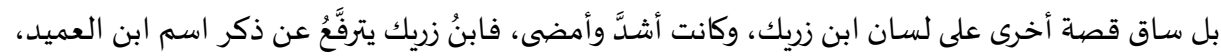

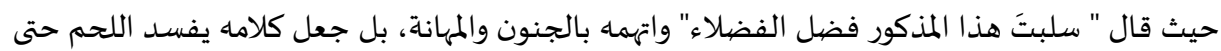

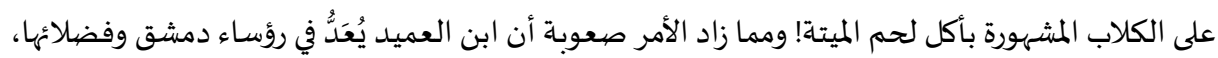

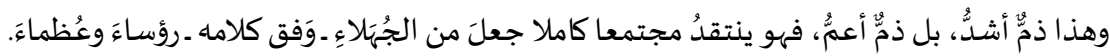

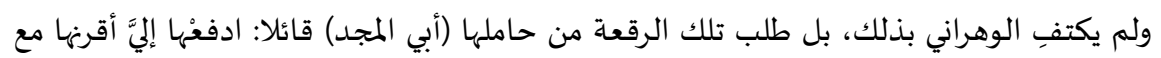

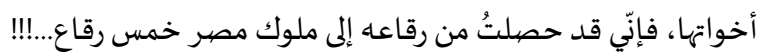

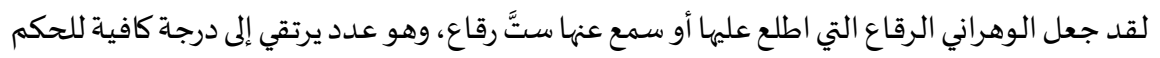

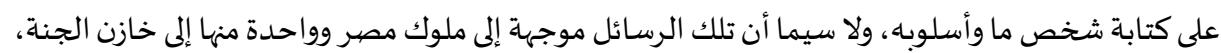

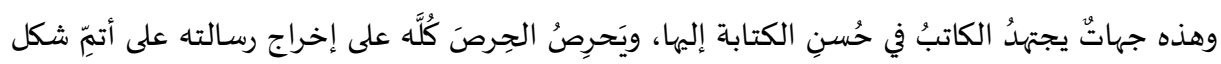
يستطيعه، ومع هذا كان الحكم عليها شديد الوطأة على النفس.

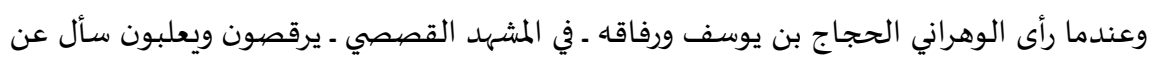

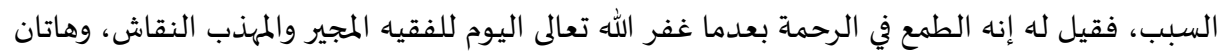
شخصيتان غائبتان عن المشهد حاضرتان في السرد، وكانت الغاية من ذكرهما أن الله قد يغفر لأعتى العتاة،

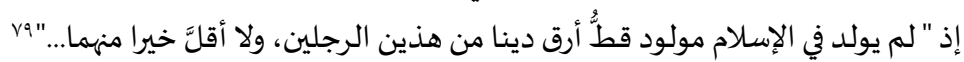

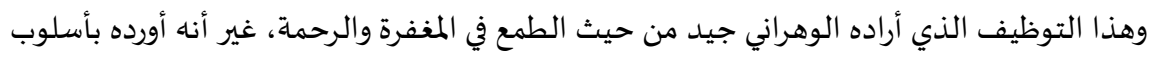

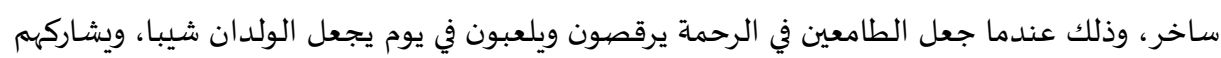
حفلتهم إبليسُ الذي توعدَه الله تعالى بالنار.

\section{خاتمة ونتيجة}

من خلال هذا البحث نجد أن الوهراني قصيد النقد و السخرية، ولم يقصيد الحديث العلمي عن يوم

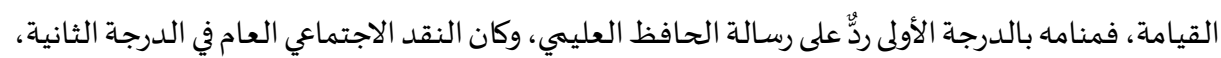

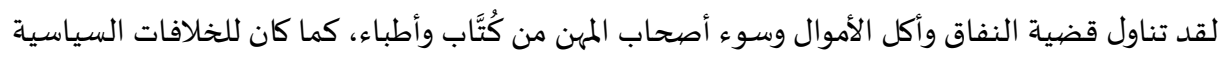
نصيب كبير في منامه وبخاصة خلاف علي بن أبي طالب مع معاوية بن أبي سفيان رضي الله عنهما، وذلك من

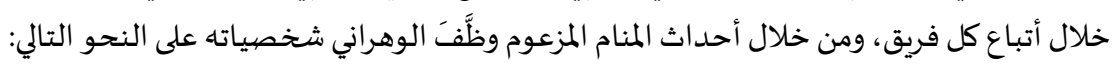

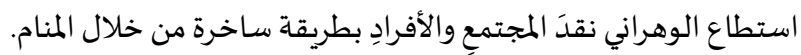

ظهرت الشخصيات السويّة (الواقعية) ظهورا واضحا وإيجابيا ومؤثرا.

ظهرت الشخصيات غير السويّة (الغرببة) ظهورا مضحكا يثير الشفقة أحيانا والسخرية أحيانا

وظَّفَ الشخصيات الغائبة توظيفا نقديا موفقا ورائعا غالبا. 
استطاع في بعض الشخصيات أن يمزج بين الحقيقة والخيال فأجاد كثيرا وأخفق قليلا. كان توظيفاه لبعض الشخصيات غير موفق، إذ نسب للملائكة ما لا يليق بهم. كانت بعض الأحداث سلبية، إذ خصنَّ بعض الأشخاص السيئين بمغفرة الله تعالى.

ابن العماد، عبدالجي بن أحمد بن محمد، شـدرات النهب في أخبار من ذهب. دمشق: دار ابن كثير، ب 199.

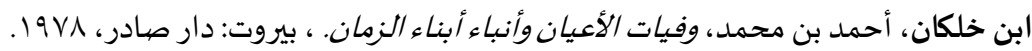

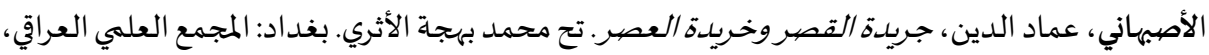
.1900

أمين، أحمد، النقل الأدبي، القاهرة: كلمات عربية للترجمة والنشر، بدون تاريخ.

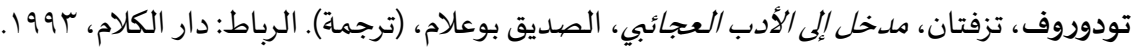

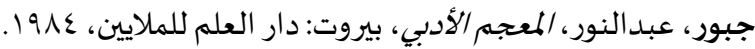

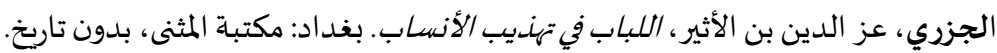

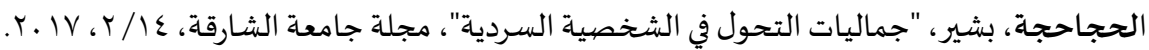

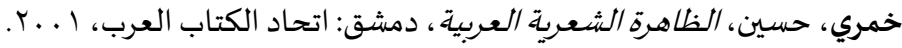

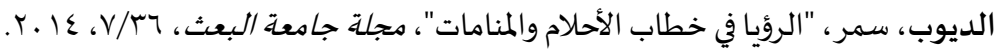
الذهبي، شمس الدين محمد بن أحمد بن عثمان، سير أعلام النبلاء، بيروت: مؤسسة الرسالة، ـ 911 أ.

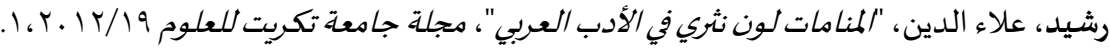

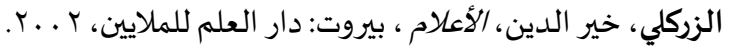

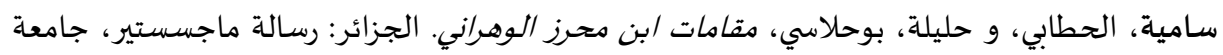

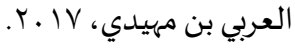

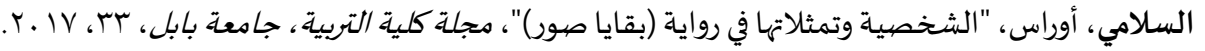
العسقلاني، ابن حجر، فتح الباري بشسح صحيح الإمام البخاري، رياض: مكتبة الملك فهد، ل . . ب.

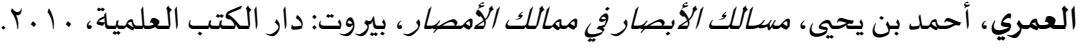

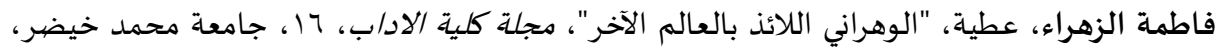

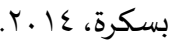

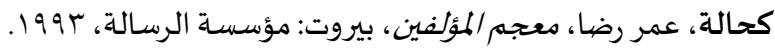

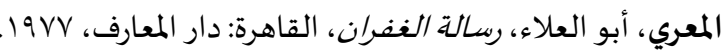

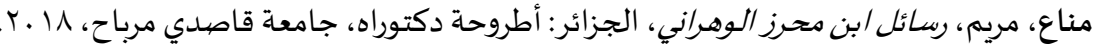

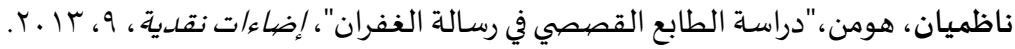

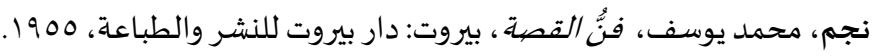

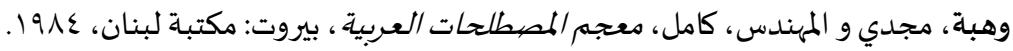

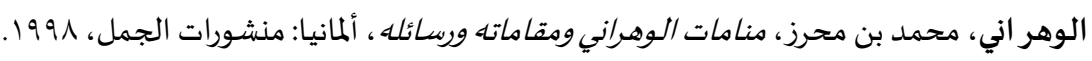




\section{Kaynakça}

el-'Askalânî, İbn Hacar, Fethu'l-Bârî bi şerhi Sahîhi'l-İmâmi'l-Buhârî, Riyad: Mektebetu'l-Melik Fehd, 2001.

el-'Umarî, Ahmed bin Yahyâ, Mesâliku'l-Ebsâr fî memâliki'l-Emsâr. Beyrut: Dâru'l-Kutubi'l-i̇lmiyye, 2010.

el-Cezerî, 'İzzuddîn İbnu'l-Esîr, el-Lubâb fî tehzîbi'l-ensâb, Bağdât: Mektebu'l-Mutenebbî, ts.

Cubûr, 'Abdunnûr, El-Mu'cemu'l-edebî, Beyrut: Dâru'l-'İlm li'l-Melâyîn, 1984.

ed-Dayyûb, Samar,"Er-Ru'ya fî hitâbi'l-ahlâm ve'l-menâmât”, Mecelletu Câmi 'ati'l-Ba 's, 36/7, 2014.

Emîn, Ahmed, en-Nakdu'l-edebî, Kahire: Kelimât 'Arabiyye li't-Tercüme ve'n-Neşr, ts.

Fâtimatu'z-Zehrâ', 'Atiyye, "El-Vehrânîyyu'l-lâ'iz bi'l-âlemi'l-âhar", Mecelletu Kulliyyeti'l-Âdâb, Câmi'at Muhammed Haydar. Sayı 16, 2014.

el-Hacâhica, Beşîr, "Cemâliyâtu't-tahavvul fi'ş-şahsiyyeti's-serdiyye", Mecellt Câmi 'ati'ş-Şârika. 14/2, 2017.

Hamrî, Huseyn, Ez-Zâhiretu'ş-şi 'riyyetu'l-'Arabiyye, Dimaşk: İttihâdu'lKuttâbi'l-'Arab, 2001.

el-Hattâbî, Sâmiye ve Bohlâsî, Halîle, Makâmat İbn Muhriz el-Vahrânî, Cezâir: Risâlet macester, Câmi'at el-'Arabî bin Muhdî, 2017.

İbn Hallikân, Ahmed bin Muhammed, Vefeyâtu'l- 'ayân ve enbâ'u ebnâ'i'zzaman, Beyrut: Dâru Sâdir, 1978.

İbnu'l-'İmâd, 'Abdulhay bin Ahmed, Şezerâtu'z-zeheb fì ahbâri men zeheb, Dimaşk: Dâru İbn Kesîr, 1989.

el-İsbahânî, 'İmâduddîn, Cerîdetu'l-'asr ve harîdetu'l-kasr, Muhammed Behcet el-Eserî (thk). Bağdat: el-Mecma'u'l-'İlmi'l-'Irâkî, 1955.

Kahhâle, Ömer Rıdâ, Mu 'cemu 'l-muellifin, Beyrut: Muessesetu'r-Risâle, 1993. el-Ma'arrî, Ebu'l-'Alâ', Risâletu'l-ğufrân, Kahire: Dâru'l-Ma'ârif, 1977.

Mennâ', Meryem, Resâ'il İbn Muhriz el-Vehrânî, el-Cezâir: Utrûhat Doktorah Câmi'at Kasdî Mirbâh, 2018.

Nazmiyân, Homin, "Dirâsetu't-tâbi'I'l-kısasî fî Risâleti'l-ğufrân", İdâ'ât nakdiyye, 9, 1984.

Necm. Muhammed Yusf, Fennu'l-kıssa, Beyrut: Dâr Beyrut li'n-Neşr, 1955.

Reşîd, 'Alâ'uddîn, "El-Menâmât levnun nesriyy fi'l-edebi'l-'Arabî”, Mecellet Câmi 'at Tikrît li'l-'Ulûm. 19/1, 2012.

es-Salâmî, Avrâs, "Eş-Şahsiyye ve temessulâtuhâ fî rivâyet Bakâyâ Suvar". Mecellet Kulliyyeti’t-Terbiye. Câmi'at Bâbil, 33, 2017.

Todorov, Tzvetan, Medhal ile 'l-edebi'l- 'acâ 'ibî. Es-Sadîk bo 'lâm (çev.), Rabat: Dâru'l-Kelâm, 1993. 
Vehbe, Mecdî ve el-Muhendis, Kâmil, Mu'cemu'l-mustalahâti'l-'Arabiyye, Beyrut: Mektebet Lübnan, 1984.

el-Vehrânî, Muhammed Muhriz, Manâmâtu'l-Vehrânî ve makâmâtuh ve resâ'iluh, el-Manyâ: Menşûrâtu'l-Cemel, 1998.

ez-Zehebî, Şemsuddîn Muhammed, Siyeru e'lâmi'n-nubelâ', Beyrut:

Muessesetu'r-Risâle, 1984.

ez-Ziriklî, Hayruddîn, el-A 'lâm, Beyrut: Dâru’l-‘ìlm li’l-Melâyîn, 2002.

هو محمد بن محمد، وقيل ابن عبدالله، صفي الدين، عماد الدين الكاتب. (أحمد بن محمد ابن خلكان، وفيات الأعيان وأنباء

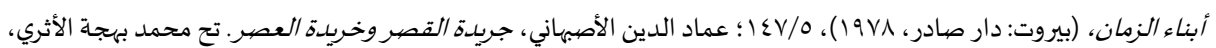

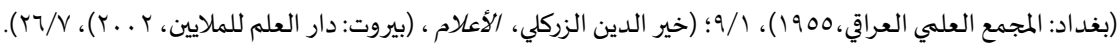

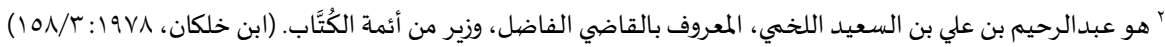

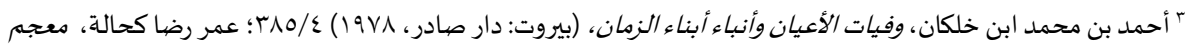

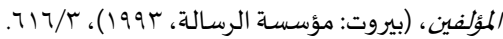

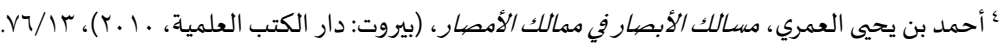

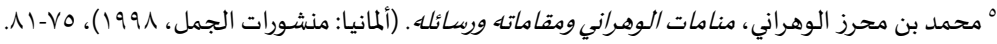

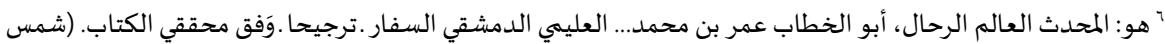

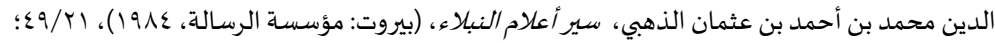

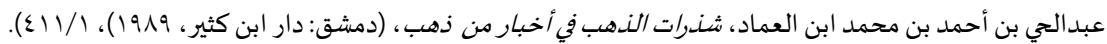

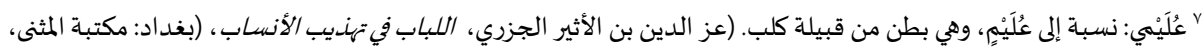

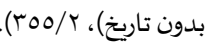

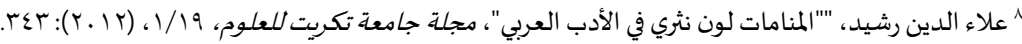

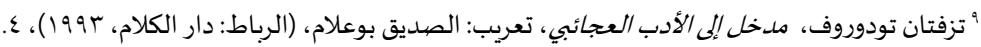

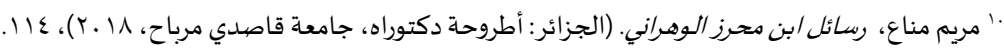

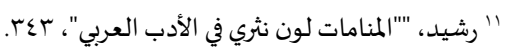

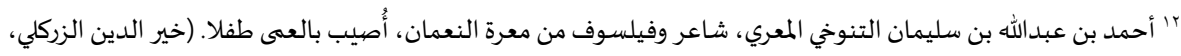

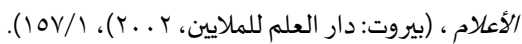
rا نقصد الحياة الدنيا والآخرة، وذلك بربطه أحداثاً ستكون في الدنيا بعد قيام القيامة والشروع في الحساب.

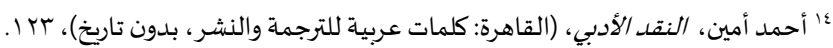

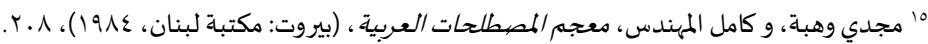

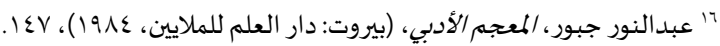

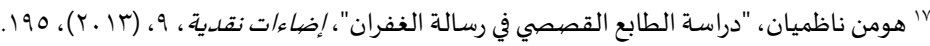

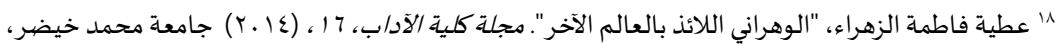
بسكرة، بris.

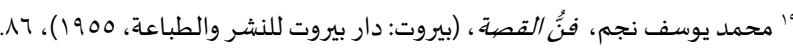

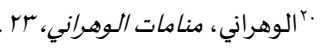

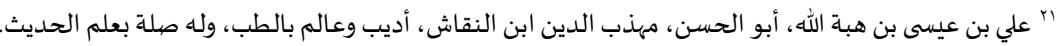

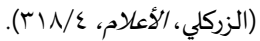

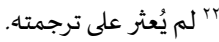




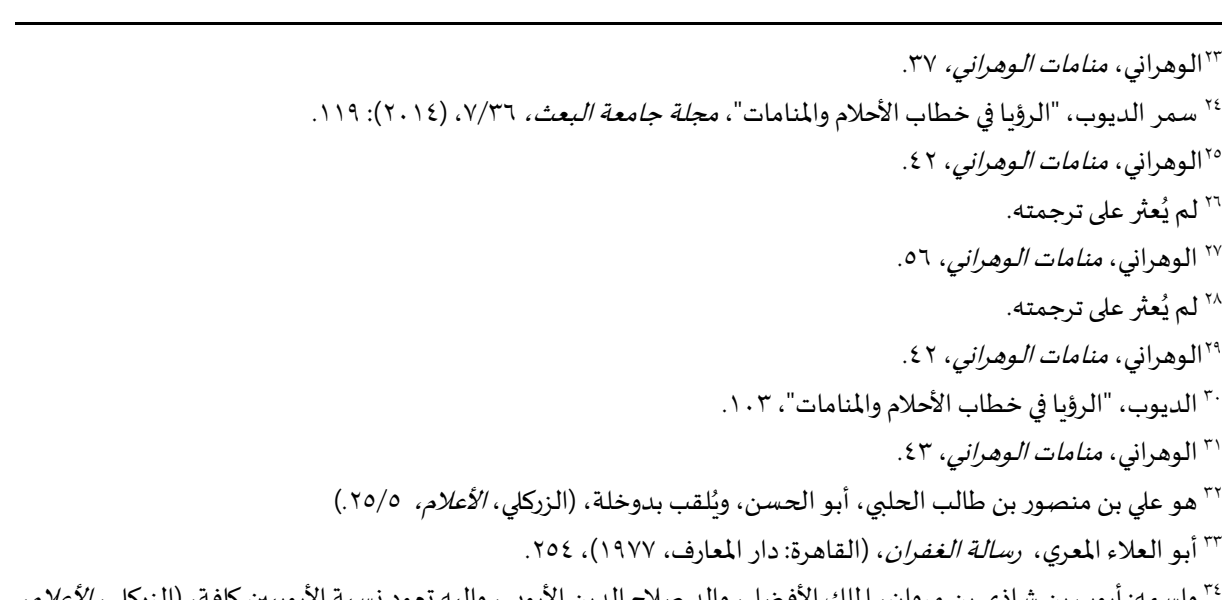

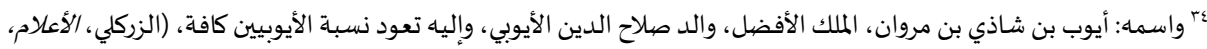

.$(r N / 4$

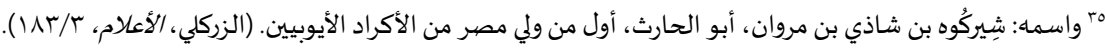

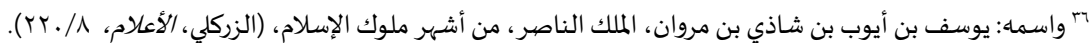

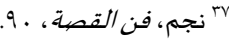

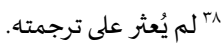

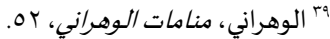
• هو عيسى بن محمد بن عيسى الحسني الطالبي، أبو محمد، ضياء الدين الهارئ الهاري، مستشار السلطان صلاح الدين الأيوبي.

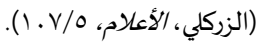

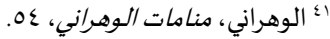

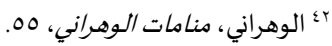

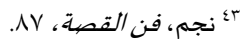

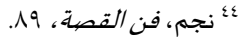
0؛ لم يُعثر على ترجمتاه. 1؛ لم يُعثر على ترجمتها..

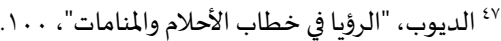

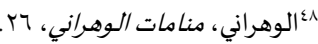

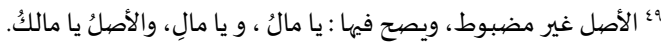
•

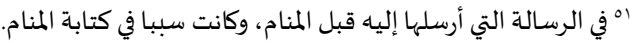

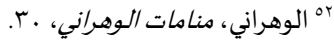

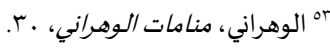
عه سامية الحطابي و حليلة بوحلاسي، مقامات /بن محرز الوهراني، (الجزائر: رسالة ماجسستير، جامعة العربي بن مهيدين .0. ، (T. IV

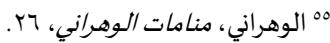

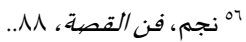

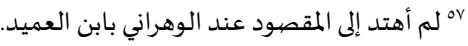


1ه الوهراني، منامات الوهراني، بr.

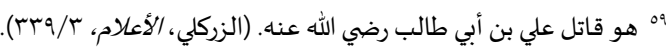

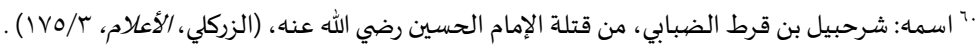

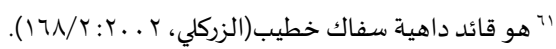

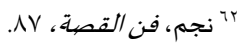

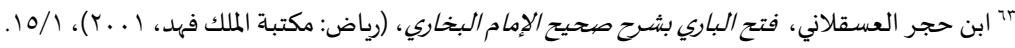
عَ لم يُعثر على ترجمتـه.

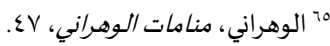

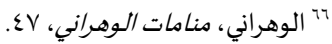

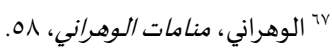

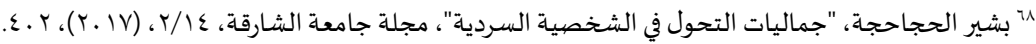

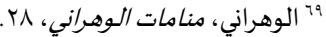

$$
\begin{aligned}
& \text { r الوهراني، منامات الوهراني، بr. }
\end{aligned}
$$

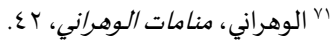

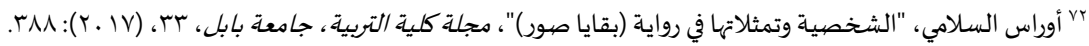

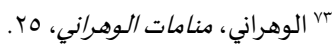

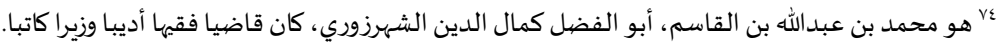

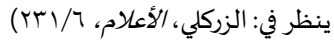

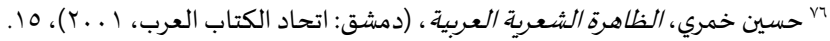

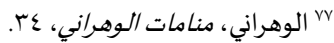

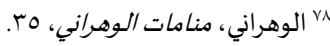

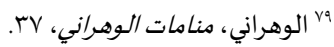

